\title{
An Overview of Biodiesel Production via Calcium Oxide Based Catalysts: Current State and Perspective
}

\author{
Hoora Mazaheri ${ }^{1}$, Hwai Chyuan Ong ${ }^{2, *}$, Zeynab Amini ${ }^{3}$, Haji Hassan Masjuki ${ }^{4}$, M. Mofijur ${ }^{2,5}$, \\ Chia Hung $\mathrm{Su}^{6}$, Irfan Anjum Badruddin ${ }^{7,8}$ and T.M. Yunus Khan ${ }^{8}$
}

1 Department of Mechanical Engineering, Faculty of Engineering, University of Malaya,

Kuala Lumpur 50603, Malaysia; hooram22@yahoo.com

2 Centre for Green Technology, Faculty of Engineering and Information Technology,

University of Technology Sydney, Sydney, NSW 2007, Australia; MdMofijur.Rahman@uts.edu.au

3 Centre for Agriculture and the Bioeconomy, Queensland University of Technology, 2 George Street, Brisbane, QLD 4000, Australia; zeynab.amini@hdr.qut.edu.au

4 Department of Mechanical Engineering, Faculty of Engineering, International Islamic University Malaysia (IIUM), Kuala Lumpur 50728, Malaysia; masjuki@iium.edu.my

5 Mechanical Engineering Department, Prince Mohammad Bin Fahd University, Al Khobar 31952, Saudi Arabia

6 Department of Chemical Engineering, Ming Chi University of Technology, New Taipei City 24301, Taiwan; chsu@mail.mcut.edu.tw

7 Research Center for Advanced Materials Science (RCAMS), King Khalid University, P.O. Box 9004, Abha 61413, Saudi Arabia; irfan@kku.edu.sa

8 Mechanical Engineering Department, College of Engineering, King Khalid University, P.O. Box 394, Abha 61421, Saudi Arabia; mtatagar@kku.edu.sa

check for updates

Citation: Mazaheri, H.; Ong, H.C.; Amini, Z.; Masjuki, H.H.; Mofijur, M.; Su, C.H.; Anjum Badruddin, I.; Khan, T.M.Y. An Overview of Biodiesel Production via Calcium Oxide Based Catalysts: Current State and Perspective. Energies 2021, 14, 3950. https://doi.org/10.3390/en14133950

Academic Editor: João Fernando Pereira Gomes

Received: 11 May 2021

Accepted: 18 June 2021

Published: 1 July 2021

Publisher's Note: MDPI stays neutral with regard to jurisdictional claims in published maps and institutional affiliations.

Copyright: (c) 2021 by the authors. Licensee MDPI, Basel, Switzerland. This article is an open access article distributed under the terms and conditions of the Creative Commons Attribution (CC BY) license (https:/ / creativecommons.org/licenses/by/ $4.0 /)$.
* Correspondence: HwaiChyuan.Ong@uts.edu.au

\begin{abstract}
Biodiesel is a clean, renewable, liquid fuel that can be used in existing diesel engines without modification as pure or blend. Transesterification (the primary process for biodiesel generation) via heterogeneous catalysis using low-cost waste feedstocks for catalyst synthesis improves the economics of biodiesel production. Heterogeneous catalysts are preferred for the industrial generation of biodiesel due to their robustness and low costs due to the easy separation and relatively higher reusability. Calcium oxides found in abundance in nature, e.g., in seashells and eggshells, are promising candidates for the synthesis of heterogeneous catalysts. However, process improvements are required to design productive calcium oxide-based catalysts at an industrial scale. The current work presents an overview of the biodiesel production advancements using calcium oxide-based catalysts (e.g., pure, supported, and mixed with metal oxides). The review discusses different factors involved in the synthesis of calcium oxide-based catalysts, and the effect of reaction parameters on the biodiesel yield of calcium oxide-based catalysis are studied. Further, the common reactor designs used for the heterogeneous catalysis using calcium oxide-based catalysts are explained. Moreover, the catalytic activity mechanism, challenges and prospects of the application of calcium oxide-based catalysts in biodiesel generation are discussed. The study of calcium oxide-based catalyst should continue to be evaluated for the potential of their application in the commercial sector as they remain the pivotal goal of these studies.
\end{abstract}

Keywords: biodiesel production; heterogeneous catalyst; alternative fuel; renewable energy; alkaline metal oxides

\section{Introduction}

The rapid depletion of fossil fuel supplies affects energy security and increases greenhouse gas emissions and carbon dioxide $\left(\mathrm{CO}_{2}\right)$ concentration in the atmosphere, and these key drivers necessitate the search for alternative sources of energy [1-3]. Energy supplies have transitioned from fossil fuels since the early twentieth century to renewable sources (at a much slower rate, though) [4,5], and some of the most remarkable alternative energy 
sources that can stand in for fossil fuels are wind, solar, water, and biofuel. Solar, wind, and hydro energy are the chief sources of electricity and heat generation used globally. In the United States, $20 \%$ of total electricity was produced from renewable sources in 2020; wind $(8.4 \%)$, hydropower (7.3\%), solar (2.3\%), biomass (1.4\%), and geothermal $(0.5 \%)[6]$. Biomass is a renewable organic material and bioenergy utilizes biomass, in order to produce heat, electricity, and biofuel, such as biogas and liquid fuels. The predominant types of renewable energy from biomass (i.e., biofuel) are biochar (solid), biodiesel and bioethanol (liquid), and bio-hydrogen, biogas, and biosynthetic gas (gaseous) [7,8]. Although energy sources other than biomass are preferred for electricity and heat generation, biofuels as liquid fuels serve as energy-dense fuels that can be blended with petroleum-based fuels, i.e., gasoline and diesel [9].

Petroleum diesel (petrodiesel) fuel exhausts emissions, such as particulate matter, nitrogen oxide (NOx), and aerosols that can cause various health issues, such as respiratory diseases, allergy, cancer, and vascular diseases [10]. Unlike petrodiesel, biodiesel does not contain any metals, residues, or sulphur aromatics, and releases minimal amounts of glasshouse gases [11,12]. In this way, biodiesel can be used in combination with petrodiesel, as they have similar characteristics [13]. Biodiesel can also be used as an alternative to fossil fuel in diesel engine with no modification [14]. However, biodiesel might not be viewed as a petrodiesel substitute; rather, it can be considered as an essential component of a secure and diverse energy supply.

Transesterification is the general process for biodiesel production, in which alcohol (chiefely methanol) and oil react, and the reaction is usually catalyzed by the utilization of a homogeneous or heterogeneous catalyst $[15,16]$. There is some technological difficulty (corrosion and emulsification) when acid or base homogeneous catalysts are applied in the reaction [17]. On the contrary, compared to homogeneous catalysts, such as potassium hydroxide $(\mathrm{KOH})$, that dissolve in the reactant [18], heterogeneous catalysts are advantageous for their easy separation, possibility of high-quality glycerol with high levels of purity $(\geq 98 \%)$ from the product, and possible reusability of the catalyst for several cycles. Therefore, transesterification via heterogeneous catalysis as a green process can value add to the process. Calcium oxide $(\mathrm{CaO})$-based catalysts are heterogeneous, low-cost, available material in abundance in nature that can be produced from waste feedstocks, such as seashells and eggshells [19]. Cao-based catalysts have relatively high activity, and their leaching problem can be overcome by supporting it on different carriers or mixing with other oxides [20].

This review focuses on biodiesel generation via transesterification reactions from a catalytic standpoint. In this regard, this review firstly discussed the heterogeneous and homogeneous catalysts, as well as their advantages and disadvantages; and secondly, evaluated $\mathrm{CaO}$ - (in the different forms of pure, supported and mixed with other oxides) catalyzed transesterification. Additionally, $\mathrm{CaO}$ catalysts derived from natural resources were reviewed and the effect of various parameters on the transesterification, including catalyst reusability, catalyst-loading amount, water content, total primary sites, calcination time and temperature, and reaction time were studied in brief. Moreover, the reactors in use for heterogeneous catalysts were discussed. Finally, the future perspective of the CaO-derived catalysts was reviewed to assess their capacity in biodiesel production.

\section{Biodiesel}

Biodiesel is a sustainable liquid fuel for transportation [21] and it has improved characteristics compared to petrodiesel, such as lower density and viscosity. The density of the fuel affects the engine's fuel injection system and the lower dense and viscous fuel leads to better atomization and mixing properties [22]. The properties of the developed biodiesel for further use as a pure compound or a blend should be tested, and the properties must be commensurate with international standards for testing biodiesel, such as EN 14,214 and ASTM D6751, according to the European Committee for Standardization and 
American Standards for Testing and Materials. The biodiesel properties were compared with petrodiesel and listed in Table 1.

Table 1. Pure biodiesel properties versus petrodiesel [23-27].

\begin{tabular}{|c|c|c|}
\hline & Biodiesel & Petrodiesel \\
\hline Exhaust emissions & Low & High \\
\hline Renewable supply & Renewable & Non-renewable \\
\hline Biodegradability & Good & Poor \\
\hline Toxicity & Non-toxic & Toxic \\
\hline Brake thermal efficiency & Low & High \\
\hline Lubricity & Good & Poor \\
\hline Combustion & Complete & Incomplete \\
\hline Carbon monoxide emissions & Low & High \\
\hline Sulphur and aromatic content & $0.0 \%$ & $\begin{array}{l}\text { Sulphur dioxide: } ~ 500 \text { ppm } \\
\text { Aromatics: } 20-40 \%\end{array}$ \\
\hline Explosively & Non-explosive & Explosive \\
\hline Flashpoint (K) & $423+1-23$ & 337 \\
\hline Cetane number & $45-70$ & $40-52$ \\
\hline Chemical structure & $\mathrm{C} 12, \mathrm{C} 14, \mathrm{C} 16, \mathrm{C} 18$ and C22 fatty acid methyl esters & C12 to $\mathrm{C} 25$ hydrocarbons \\
\hline Oxygen content $(\%)$ & 11 & ${ }^{*} \mathrm{~N} / \mathrm{A}$ \\
\hline $\begin{array}{l}\text { Cold flow properties } \\
\text { (Solidification) }\end{array}$ & Rapid & Gradual \\
\hline Conductivity & High; >500 pico S/m & Low \\
\hline
\end{tabular}

${ }^{*} \mathrm{~N} / \mathrm{A}=$ not available/not applicable.

One of the essential factors for biodiesel generation is its capacity to be generated through a broad diversity of existing feedstocks, which are available in abundance and are at low cost [13]. The existing feedstocks for biodiesel generation are categorized into four groups; animal fat, edible vegetable oil, non-edible vegetable oil and waste cooking oil (WCO) [26,28]. Biodiesel generated from edible vegetable oils have a relatively high yield due to their lower free fatty acids (FFA) content, and their transesterification process is simpler and more accessible. However, due to the "food versus fuel" debate, which emphasizes insufficient human food supply in the future; biodiesel production from edibleplant sources is not desired [29]. On the contrary, non-edible vegetable oils are promising feedstocks for biodiesel production because they have no conflict with the stability of the food supply [30]. WCO is one example of non-edible vegetable oil with a promising choice due to its low cost as compared to fresh vegetable oil. Methanol reacts with the triglycerides of the oil process, which is usually catalyzed by a catalyst and the general equation of this reaction is shown in Figure 1. Catalysts improve the reaction time and yield, and a whole range of homogeneous and heterogeneous catalysts are applied in transesterification.

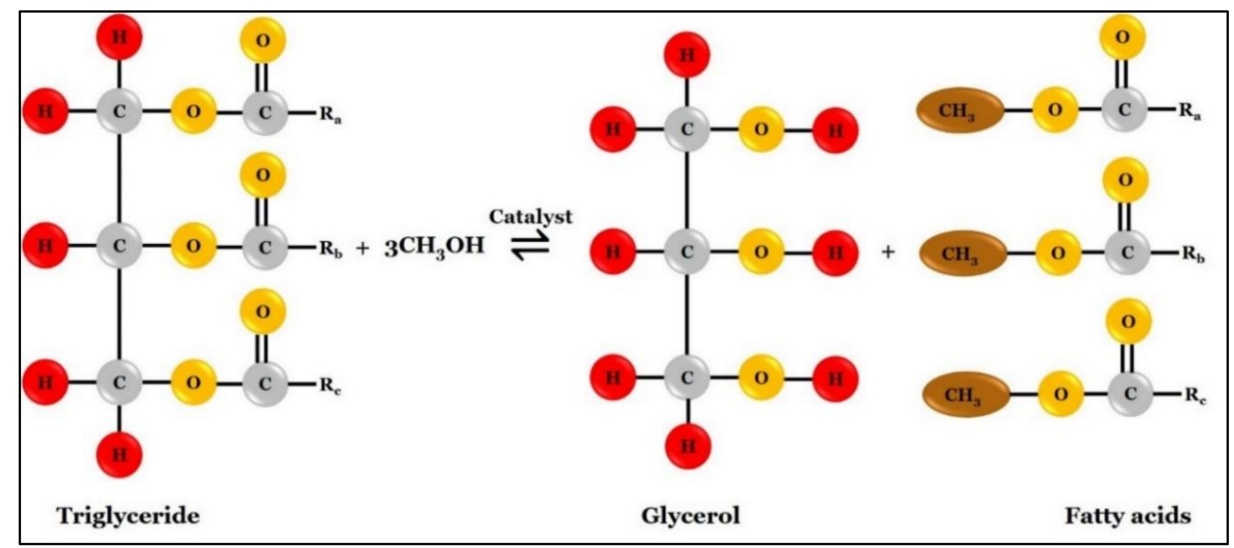

Figure 1. The transesterification process for biodiesel production $[31,32]$. 


\section{Catalysts Applied in the Transesterification}

Catalyst types have a crucial impact on the transesterification process as it expedites the reaction and a lower amount of alcohol is required for the conversion [33]. Therefore, the selection of an appropriate catalyst for an economic generation of biodiesel is vital. Catalysts are mostly categorized into three groups; homogeneous (alkalis and acids), heterogeneous (solid base or acid) and biocatalyst. During transesterification, homogeneous catalyst remains the same (liquid) phase to that of the reactant, while heterogeneous catalyst persists in being in a different phase (i.e., solid, immiscible liquid or gaseous) to that of the reactant. Enzyme catalysts have gained significant attention since they can hinder soap formation, and thus, the purification procedure is effortless. However, due to long-lasting reaction time and being overpriced, enzyme catalysts are less applied commercially [34].

Alkali homogeneous catalysts, including $\mathrm{KOH}$ and sodium hydroxide $(\mathrm{NaOH})$, are conventional commercially used catalysts for being low-cost. Further, $\mathrm{NaOH}$ and $\mathrm{KOH}$ are the most viable catalysts for mass production since the transesterification process using basic catalysts is performed under low pressure and temperature conditions, and the conversion rate is outstanding with no intermediate steps. The basic homogeneous catalysts are extremely hygroscopic and able to absorb water from the air throughout the storage. The basic homogeneous also produce water when dissolved in the alcohol reactant and thus affect the yield. Application of homogeneous catalysts in transesterification has several drawbacks such as the necessity for washing the products for catalyst removal and product cleaning and thus higher costs, and an appreciable amount of product loss in some cases is inevitable. Further, the method which is used to remove the homogeneous catalyst is arduous; thus, replacing homogeneous catalysts with heterogeneous catalysts is a tactic to diminish the cost of biodiesel production [35]. Therefore, heterogeneous catalysts are promising candidates for the production of biodiesel from vegetable oils [36]. Solid heterogeneous catalysts are non-corrosive and can be utilized in a fixed-bed reactor, resulting in protected, inexpensive and more environment-friendly processes. Moreover, solid heterogeneous catalysts are recyclable and are feasible for continuous mass production. In comparison with biodiesel production by a homogeneous catalyst, less wastewater is produced by using heterogeneous catalysts, and hence the sewage treatment costs are reduced [37]. Solid heterogeneous catalysts can stimulatingly catalyze the transesterification, which can eliminate the pre-esterification stage, thus, these catalysts are especially suitable for those feedstocks with high free fatty acid (FFA) volume [37]. Solid catalysts are either acid or alkaline, and solid heterogeneous alkaline catalysts are 4000 times faster than acid catalysts in terms of reaction rate [25,38]. Heterogeneous alkali catalysts fall into one of the following categories in relation to their active basic sites: Alkaline earth metal oxides, supported alkaline earth metal oxides, supported alkali metals, alkali and alkaline earth mixed, zeolites and modified zeolites, hydrotalcite/layered double hydroxides, rare earth/lanthanide-based, ion exchange resin, zirconia-based and other materials [39]. Alkaline earth metal oxides such as $\mathrm{CaO}$, magnesium oxide $(\mathrm{MgO})$, barium oxide $(\mathrm{BaO})$, and strontium oxide $(\mathrm{SrO})$ are used in transesterification [40]; these metal oxides become active and are used in the reaction after a thermal pretreatment [41].

\section{CaO-Based Catalysts}

Among alkaline earth metals, $\mathrm{CaO}$ has received much attention due to its reasonable price, low solubility in methanol, low toxicity and high availability from natural resources [42]. The preparation of $\mathrm{CaO}$ is simpler compared to many other solid catalysts and its catalytic activity can be augmented by applying thermal calcination. Various precursor salts, such as carbonate, hydroxide, oxalate, and acetate monohydrate are utilized in $\mathrm{CaO}$ catalyst preparation [43]. It is noteworthy that exposure of $\mathrm{CaO}$ to air, even for a few seconds, can deactivate the catalyst [44]. However, it is possible to reactivate it by calcination in a furnace at high temperatures.

The mechanism of CaO-catalyzed transesterification is shown in Figure 2 [38]. Firstly, methoxide anion forms as a result of proton removal from methanol by basic sites. Secondly, 
alkoxy carbonyl intermediate assembles due to the effect of the methoxide anion on the carbonyl carbon of triglyceride. Alkoxy carbonyl transforms into a firmer structure, i.e., fatty acid methyl ester (FAME) and anion of diglyceride; methoxide cation draws the anion of a diglyceride, which results in the development of diglyceride. The sequence is repeated twice for the carbon chain of fatty acids $\left(R_{2}\right.$ and $\left.R_{3}\right)$.

(1)

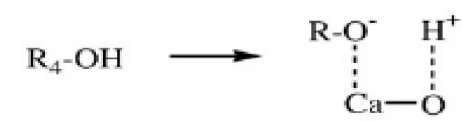

(2)

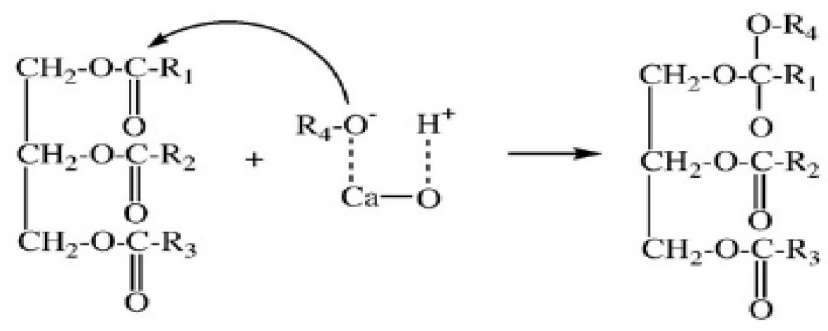

(3)

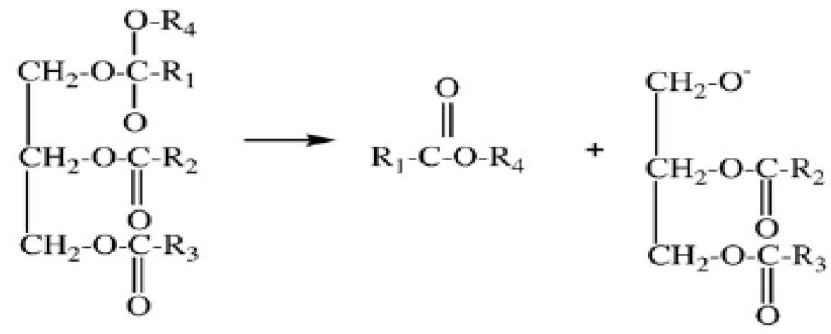

(4)
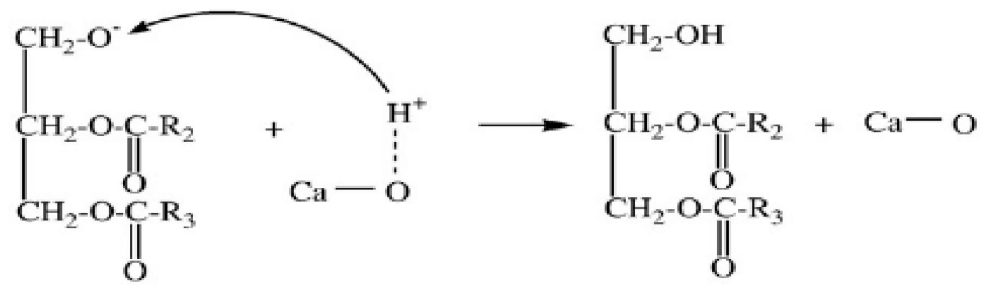

Figure 2. Mechanism of CaO-catalyzed transesterification [38]. $R_{1}, R_{2}, R_{3}$ are carbon chain of fatty acid and $R_{4}$ is alkyl group of the alcohol.

CaO-based catalysts will be activated after thermal calcination in high temperatures. The activity of the pure $\mathrm{CaO}$ are increased by increasing the number of basic sites by doping with alkali and organic compounds [42]. Mixing with metal oxides, such as lanthanum, zinc, and cerium oxides is another feasible method to improve the catalytic activity of pure $\mathrm{CaO}$. Further, $\mathrm{CaO}$ can be loaded onto several potential carriers (supported $\mathrm{CaO}$ ). $\mathrm{CaO}$ is commonly obtained from various kinds of seashells and eggshells and can be applied in transesterification as a heterogeneous catalyst in different forms; neat, supported, and mixed.

\subsection{Pure CaO Catalyst}

Pure $\mathrm{CaO}$ can catalyze the transesterification of methanol with different oils such as WCO, palm, canola, soybean, rubber seed, and Bombax ceiba [45-53]. Like other CaObased catalysts, pure $\mathrm{CaO}$, irrespective of its source, are activated by subjecting it to high temperatures. The utilization of pure $\mathrm{CaO}$, either commercial or derived from variable sources such as wastes, and their reaction conditions for biodiesel generation are reviewed (summarized in Table 2) and discussed in this part. 
Table 2. Pure CaO-based catalysts type and the reaction conditions in biodiesel production.

\begin{tabular}{|c|c|c|c|c|c|c|c|c|}
\hline $\begin{array}{c}\text { Feedstock } \\
\text { (Oil) }\end{array}$ & $\begin{array}{l}\text { Catalyst } \\
\text { Type }\end{array}$ & $\begin{array}{c}\text { Temperature } \\
\left({ }^{\circ} \mathrm{C}\right)\end{array}$ & $\begin{array}{c}\text { Molar Ratio } \\
\text { (Methanol: Oil) }\end{array}$ & $\begin{array}{l}\text { Catalyst } \\
(w t \%)\end{array}$ & $\begin{array}{l}\text { Time } \\
\text { (min) }\end{array}$ & $\begin{array}{c}\text { Yield } \\
(w t \%)\end{array}$ & $\begin{array}{l}\text { Reusability } \\
\text { (Cycle) }\end{array}$ & Reference \\
\hline Goat fat & Nano based & 70 & $12: 1$ & 1 & 180 & 93.7 & 3 & [54] \\
\hline WCO & Commercial & 80 & $1: 1$ & 3.0 & 120 & 96.0 & $\mathrm{~N} / \mathrm{A}$ & [46] \\
\hline Rapeseed & Nano based & 65 & $1: 8$ & 5 & 240 & 92.0 & $\mathrm{~N} / \mathrm{A}$ & [55] \\
\hline Bombax ceiba & Nano based & 65 & 10.4 & 1.5 & 705 & 96.2 & 5 & [45] \\
\hline Soybean & Nanocrystalline & 60 & $6: 1$ & 4.0 & 80 & 89.9 & 3 & [47] \\
\hline Palm & Lime based & 65 & $15: 1$ & 6.0 & 120 & 97.0 & 4 & [48] \\
\hline WCO & $\begin{array}{c}\text { Chicken manure } \\
\text { based }\end{array}$ & 65 & $15: 1$ & 7.5 & 360 & 90.0 & $\mathrm{~N} / \mathrm{A}$ & [49] \\
\hline Canola & FPC based & 60 & $12: 1$ & 5.0 & 90 & 96.0 & 7 & [50] \\
\hline Canola & Dolomite based & 60 & $9: 1$ & 5.0 & 90 & 97.4 & 4 & [51] \\
\hline Palm & Commercial & 60 & $9: 1$ & 2.0 & 240 & 84.5 & 3 & [52] \\
\hline
\end{tabular}

Commercial $\mathrm{CaO}$ could efficiently catalyze the conversion of WCO to biodiesel [46]. The activity of calcined $\mathrm{CaO}$ was significantly increased when it was added to methanol, and under the optimized conditions at $3.0 \%$ catalyst concentration at $80{ }^{\circ} \mathrm{C}$ temperature, 1:6 oil to methanol molar ratio, and 120 min reaction time showed $96 \%$ of biodiesel yield. $\mathrm{CaO}$ nanoparticles were used in the transesterification of Bombax ceiba oil and a high FAME yield of $96.2 \%$ was obtained under the following reaction conditions: At 10.4:1 methanol to oil molar ratio with $1.5 \%$ catalyst in $70.5 \mathrm{~min}$ at $65^{\circ} \mathrm{C}$ [45]. The nanocrystalline $\mathrm{CaO}$ catalyst was developed by ultrasound-assisted emulsion-based method and the developed catalyst manifested 1.5 times higher surface area and 1.3 times smaller crystallite size and particle size compared to commercial $\mathrm{CaO}$ catalyst [47]. At optimal conditions, the synthesized catalyst exhibited an $18.9 \%$ enhanced conversion rate of oil as compared to the commercial $\mathrm{CaO}$ catalyst. The $\mathrm{CaO}$ nanocatalyst was developed and used in the transesterification of goat fat and the biodiesel yield was reported $93.72 \%$ during the transexterification for $3 \mathrm{~h}$ at $70{ }^{\circ} \mathrm{C}$ using $1 \%$ catalyst at molar ratio of $12: 1$ [54]. The assessment of catalyst reusability indicate that it can be used fot at least three cycles with the biodiesel conversion efficiency of more than $80 \%$. Nano $\mathrm{CaO}$ was applied in the rapeseed transesterification reaction and $92.0 \%$ yield was achieved at 1:8 methanol to oil molar ratio with 5.0 catalyst at $65{ }^{\circ} \mathrm{C}$ [55]. The activity of original hydrated lime and hydrated lime derived $\mathrm{CaO}$ were examined in the transesterification of palm oil and $97.0 \%$ yield was achieved when using hydrated lime derived $\mathrm{CaO}$ at $15: 1$ methanol to oil molar ratio with 6.0 catalyst at $65{ }^{\circ} \mathrm{C}$ in $2 \mathrm{~h}$ [48]. The hydrated lime-derived $\mathrm{CaO}$ presented a greater surface area and pore volume than the synthetic one.

Catalyst production from waste resources can exert influence on the environment by lowering the disposal of those wastes and the utilization of waste material for catalyst production has added benefits in terms of economics and profitability. However, very scant work has been reported on the utilization of waste-derived $\mathrm{CaO}$ in transesterification. $\mathrm{CaO}$ catalysts derived from chicken manure was developed [49]. The manure was subjected to calcination at $850{ }^{\circ} \mathrm{C}$ in order to obtain the active $\mathrm{CaO}$ and the developed $\mathrm{CaO}$ catalyst had high catalytic activity for transesterification of WCO. The optimum conditions for catalyst synthesis were $7.5 \%$ catalyst, $15: 1$ of methanol to oil molar ratio and $65{ }^{\circ} \mathrm{C}$ reaction temperature, and a FAME yield of $90.0 \%$ was achieved at these conditions [49]. $\mathrm{CaO}$ nanoparticles were produced from filter press cake (FPC) waste [56]. Managing FPC waste is a serious challenge for sugar-producing facilities, but FPC waste can be used as a source for catalyst production. The FPC was subjected to calcination at $900{ }^{\circ} \mathrm{C}$ for $2 \mathrm{~h}$ for activation, followed by a surfactant-hydration method for the production of $\mathrm{CaO}$ nanoparticles [50], and yield of over $96.0 \%$ was achieved after reacting canola oil and methanol.

Ultrasonic-assisted transesterification is an efficient method when using $\mathrm{CaO}$ as a catalyst as it can crush the catalyst into smaller parts, leading to more basic sites. Increased basic sites have a key role in the efficiency of CaO-catalyzed transesterification. Further, it reduces the time needed for oil conversion to biodiesel. For instance, $\mathrm{CaO}$ obtained from dolomite was applied in the ultrasonic-assisted transesterification of canola oil, and a yield 
of $97.4 \%$ was obtained after $90 \mathrm{~min}$ of reaction [51]. Moreover, $84.5 \%$ yield was achieved when $\mathrm{CaO}$ catalyzed the ultrasound-assisted transesterification of palm oil at the following reaction conditions: $2.0 \%$ catalyst, $60{ }^{\circ} \mathrm{C}$ temperature, 9:1 methanol to oil molar ratio and reaction time of $4 \mathrm{~h}$ [52].

\subsection{Mixed Oxides $\mathrm{CaO}$ Catalysts}

Mixing oxides, such as $\mathrm{CaO}$ with other elements (e.g., $\mathrm{Zn}, \mathrm{Ba}, \mathrm{Mg}$, $\mathrm{Fe}$, etc.) is a method used for synthesizing a catalyst with increased basic cites and improved stability. In this part, the utilization of mixed $\mathrm{CaO}$ and their reaction conditions, as well as their preparation method, were reviewed and summarized in Table 3.

Table 3. Mixed oxide $\mathrm{CaO}$ catalyst and reaction conditions in biodiesel production.

\begin{tabular}{|c|c|c|c|c|c|c|c|c|c|}
\hline $\begin{array}{l}\text { Feedstock } \\
\text { (Oil) }\end{array}$ & Catalyst & Synthesis Method & $\begin{array}{c}\text { Temperature } \\
\left({ }^{\circ} \mathrm{C}\right)\end{array}$ & $\begin{array}{c}\text { Molar Ratio } \\
\text { (Methanol: Oil) }\end{array}$ & $\begin{array}{l}\text { Catalyst } \\
(w t \%)\end{array}$ & $\begin{array}{l}\text { Time } \\
(\mathrm{min})\end{array}$ & $\begin{array}{l}\text { Yield } \\
(w t \%)\end{array}$ & $\begin{array}{c}\text { Reusability } \\
\text { (Cycle) }\end{array}$ & Reference \\
\hline $\begin{array}{l}\text { Calophyllum } \\
\text { inophyllum }\end{array}$ & $\mathrm{Zn}-\mathrm{CaO}$ & $\begin{array}{l}\text { Precipitation } \\
\text { Calcination }\end{array}$ & 55 & $9: 1$ & 6.0 & 80 & 89.0 & 4 & {$[65]$} \\
\hline $\begin{array}{l}\text { Elaeis } \\
\text { guineensis }\end{array}$ & $\mathrm{CaO}-\mathrm{MgO}$ & $\begin{array}{l}\text { Co-precipitation } \\
\text { Calcination }\end{array}$ & 60 & $15: 1$ & 4.0 & 360 & 99.0 & 5 & [57] \\
\hline Waste edible & $\mathrm{CaO}-\mathrm{MgO}$ & Wet impregnation & 69.4 & $17: 1$ & 4.6 & 428 & 98.4 & 6 & [58] \\
\hline Soybean & $\mathrm{MgFe}_{2} \mathrm{O}_{4}$ and $\mathrm{CaO}$ & Alkali precipitation & 70 & $12: 1$ & 1.0 & 180 & 98.3 & 5 & [59] \\
\hline Soybean & $\mathrm{Ca}-\mathrm{Mg}$ & $\begin{array}{l}\text { Oxalate } \\
\text { precipitation }\end{array}$ & 70 & $12: 1$ & 1.0 & 120 & 98.0 & 5 & {$[60]$} \\
\hline Jatropha Curcas & $\mathrm{CaO}-\mathrm{ZnO}$ & Co-precipitation & 120 & $25: 1$ & 3.0 & 180 & 94.0 & $\mathrm{~N} / \mathrm{A}$ & {$[61]$} \\
\hline Karanj & $\mathrm{CaO}-\mathrm{La}_{2} \mathrm{O}_{3}-\mathrm{Al}_{2} \mathrm{O}_{3}$ & $\begin{array}{l}\text { Co-precipitation } \\
\text { Calcination }\end{array}$ & 150 & $9: 1$ & 5.0 & 180 & 97.0 & $\mathrm{~N} / \mathrm{A}$ & [62] \\
\hline Sunflower & $\mathrm{CaTiO}_{3}$ and $\mathrm{CaO}$ & $\begin{array}{l}\text { Mechanochemical } \\
\text { Calcination }\end{array}$ & 60 & $6: 1$ & 10.0 & 600 & 98.1 & $\mathrm{~N} / \mathrm{A}$ & [63] \\
\hline Palm & $\mathrm{Ca}, \mathrm{Zn}$, and $\mathrm{Al}$ & $\begin{array}{l}\text { Dissolution } \\
\text { Precipitation }\end{array}$ & 65 & $30: 1$ & 10.0 & 180 & 99.9 & $\mathrm{~N} / \mathrm{A}$ & [64] \\
\hline
\end{tabular}

A Highly basic bimetallic alkaline earth metal oxide $(\mathrm{CaO}-\mathrm{MgO})\left(750 \mu \mathrm{mol} \mathrm{g}^{-1}\right)$ was produced by using synergistic effects [57] and the FAME yield of $\geq 99.0 \%$ was obtained under the optimal condition of $4.0 \%$ catalyst at a temperature of $60^{\circ} \mathrm{C}$ and $6 \mathrm{~h}$ reaction time. The results showed that the basicity of mixed $\mathrm{CaO}-\mathrm{MgO}(\mathrm{CM}-1.0)$ was higher in comparison with the pure $\mathrm{CaO}$ catalyst. The atomic absorption spectroscopy method was used to evaluate the leaching of the catalyst and the result showed that the catalyst was stable up to five cycles. $\mathrm{CaO}-\mathrm{MgO}$ nanocatalyst was used to produce FAME from waste edible oils; the catalyst was successfully reused for up to six cycles and a maximum biodiesel conversion yield of $98.37 \%$ was obtained [58].

The utilization of magnetic materials eliminates the need for conventional filtration and purification. A magnetic nanoparticle catalyst (i.e., $\mathrm{MgFe}_{2} \mathrm{O}_{4}$ and $\mathrm{CaO}$ ) was synthesized by using the synergistic effect, followed by its application in the transesterification of soybean [59] and the FAME yield obtained was 5.9\% higher than pure CaO-catalyzed reaction. Additionally, the developed catalyst was found to be more active and more water and acid resistant than the neat $\mathrm{CaO}$. Calcium oxalate and magnesium oxalate can be used as precursors to generate $\mathrm{Ca}-\mathrm{Mg}$ mixed oxide catalyst and the bimetallic catalyst showed a better surface area than the pure $\mathrm{CaO}$ [60]. The FAME yield of $98.4 \%$ and $92.8 \%$ were reported for $\mathrm{Ca}-\mathrm{Mg}$, and pure $\mathrm{CaO}$, respectively and the higher yield of mixed oxide catalyst was attributed to the larger surface area.

Different types of mixed earth metal oxides (e.g., CaO-MgO, $\mathrm{CaO}-\mathrm{ZnO}, \mathrm{CaO}-\mathrm{Lanthanum}$ (III) oxide $\left(\mathrm{La}_{2} \mathrm{O}_{3}\right)$, and $\left.\mathrm{MgO}-\mathrm{ZnO}\right)$ were investigated in terms of catalysis and it was noted that due to the increased basic density and strength, mixed metal oxides had improved activity in the transesterification than the single metal oxides [61]. The biodiesel yield of $94.0 \%$ was achieved when $\mathrm{CaO}-\mathrm{ZnO}$ was applied in the transesterification of Jatropha curcas [61]. Transesterification of palm oil (having high acid volume) and Karanja oil (having low acid volume) $\mathrm{CaO}-\mathrm{La}_{2} \mathrm{O}_{3}$-Aluminium oxide $\left(\mathrm{Al}_{2} \mathrm{O}_{3}\right)$ catalyzed by mixed- 
oxides were tested and FAME yield of $97.0 \%$ was obtained [62]. In this study, dimethyl carbonate (DMC) was used instead of methanol due to its improved properties, such as nontoxicity, non-corrosive and being active in the reaction. Calcium-containing perovskites $\mathrm{CaTiO}_{3}, \mathrm{CaMnO}_{3}$, and $\mathrm{CaZrO}_{3}$ were prepared and used to catalyze the transesterification of sunflower oil [63], and the pure perovskite phase showed low or no catalytic activity. The FAME yield of $98.1 \%$ was achieved after a $10 \mathrm{~h}$ reaction at $60{ }^{\circ} \mathrm{C}$ when $\mathrm{CaTiO}_{3}$ catalyzed the reaction.

On the same subject of using mixed metal oxide for biodiesel production, transesterification of refined, bleached deodorized palm oil with methanol using a new heterogeneous alkali catalyst was studied. A mixture of $\mathrm{Ca}, \mathrm{Zn}$, and $\mathrm{Al}$ compounds was prepared using the dissolution-precipitation method using Meretrix meretrix seashells as a source of $\mathrm{CaO}$, in the presence of zinc nitrate and alumina as binder precursors. FAME yield of $99.9 \%$ was achieved when 30:1 methanol to oil molar ratio, 10.0\% catalyst ratio, $3 \mathrm{~h}$ reaction time and $65{ }^{\circ} \mathrm{C}$ applied to the system [64].

\subsection{Supported and Loaded CaO Catalysts}

Utilization of support or carrier would improve the stabilizing characteristic of the $\mathrm{CaO}$ catalyst and would decrease the leaching. Various methods were applied for the development of supported $\mathrm{CaO}$, including wet impregnation, precipitation and co-precipitation, followed by calcination to activate the catalyst. Alumina [66], zeolites [67], and silica [68] are the common materials for supporting $\mathrm{CaO}$ catalysts for biodiesel production. An overview of supported $\mathrm{CaO}$ catalyzed transesterification and its different parameters were listed in Table 4 and reviewed in this part.

$\mathrm{CaO}$ supported with Al-MCM41 was prepared via the sono-dispersion and wet impregnation method and the catalyst was used in the transesterification of sunflower oil [69]. It was found that the biodiesel conversion and quality increased as $\mathrm{CaO}$ was loaded due to its basicity. Diatomite supported by $\mathrm{CaO} / \mathrm{MgO}$ was generated by the impregnation method and was then utilized in the transesterification of WCO, and the yield of $96.5 \%$ was obtained under the following experimental condition: temperature of $90^{\circ} \mathrm{C}$, methanol to oil molar of ratio 1:15, catalyst amount of $6.0 \%$ and reaction time of $2 \mathrm{~h}$ [70]. $\mathrm{CaO}$, supported with silica, was successfully synthesized by using the wet impregnation method, and a yield of $87.5 \%$ was achieved, which was higher than the yield achieved when neat $\mathrm{CaO}$ was used [71]. Structured catalyst reactors, such as those based on the monolithic catalyst are a captivating method for biodiesel production. However, it should be noted that a high affinity between the support and catalyst could lead to the deactivation of the catalyst. The metallic citrates decomposition method was used to prepare mixed calcium/cerium oxide $(\mathrm{CaO} / \mathrm{Ce})$ both in powder and structured shapes and the Ca-Ce mixed oxides deposited on structured catalysts using Fecralloy monoliths for their use in the transesterification of sunflower oil [72]. $\mathrm{KOH}$ catalyst supported on $\mathrm{CaO}$ obtained from animal bones was utilized in the transesterification of Jatropha curcas oil and $\mathrm{CaO}$ oxide modification was carried for increasing the surface area and basicity of the catalyst [73]. The synthesized catalyst exhibited high performance and stability, which therefore led to a high FAME conversion rate of $96.1 \%$ under the following reaction condition: methanol/oil molar ratio, $9: 1$, catalyst concentration, $6.0 \%$ at a temperature of $70{ }^{\circ} \mathrm{C}$ at a reaction time of $3 \mathrm{~h}$. Immobilization of $\mathrm{CaO}$ onto polymeric mats fibers was reported for biodiesel production, and this polymer had been used in the immobilization of lipase but never for loading heterogenous catalysts. The catalyst was subsequently applied in the transesterification of canola oil and methanol [74].

Zeolites have been widely used as a carrier in biodiesel production in the past decade [75-78]. Zeolites with specific pore structure and surface hydrophobicity can be modified depending on the substrate's polarity and size, and hence, molecules with diameters smaller than the proper catalyst size can enter the cavity and diffuse [38]. In this regard, how hierarchical (h) Zeolite Socony Mobil 5- (ZSM-5) supported CaO performs as a catalyst in biodiesel production from waste palm oil was investigated. The catalytic activity 
of $\mathrm{CaO}$ was enhanced after support on h-ZSM-5, and resulted in an improvement of FAME conversion from $93.2 \%$ to $95.4 \%$ at the following reaction conditions: $6 \mathrm{~h}$ reaction time, $3.0 \%$ catalyst amount, $12: 1$ methanol to oil molar ratio and $65^{\circ} \mathrm{C}$ reaction temperature [79]. $\mathrm{CaO}$ catalysts were supported with crystalline sodium $\mathrm{Y}(\mathrm{NaY})$ zeolite $(\mathrm{Si} / \mathrm{Al}=3.24)$, KL zeolite $(\mathrm{Si} / \mathrm{Al}=6.2)$ and NaZSM-5 zeolite $(\mathrm{Si} / \mathrm{Al}=40)$, which was prepared by microwave irradiation [67]. Further, these supported $\mathrm{CaO}$ catalysts were applied in the transesterification of soybean oil and their functions were compared to that of pure $\mathrm{CaO}$. The results showed that the use of zeolite as support for $\mathrm{CaO}$ boosted the catalysis performance due to more basic sites and increased surface area. Furthermore, it was found that $\mathrm{CaO} / \mathrm{NaY}$ had the best activity and a biodiesel yield of $95.0 \%$ was achieved with $3.0 \%$ catalyst, methanol to oil molar ratio of 9:1 and, reaction temperature of $65^{\circ} \mathrm{C}$ within the reaction time of $3.0 \mathrm{~h}$ [67]. Pure cancrinite zeolitic material was utilized as catalyst support of $\mathrm{CaO}$ derived from waste chicken eggshells. FAME yield of $96.5 \%$ was obtained in the methanolysis of sunflower oil at $60{ }^{\circ} \mathrm{C}$ for $2 \mathrm{~h}$ with $4.0 \%$ of this catalyst by maintaining molar ratio of 12 [80].

Table 4. Utilization of supported $\mathrm{CaO}$ catalysts in transesterification.

\begin{tabular}{|c|c|c|c|c|c|c|c|c|}
\hline $\begin{array}{l}\text { Feedstock } \\
\quad \text { (Oil) }\end{array}$ & Synthesis Method & $\begin{array}{c}\text { Temperature } \\
\left({ }^{\circ} \mathrm{C}\right)\end{array}$ & $\begin{array}{l}\text { Molar Ratio } \\
\text { (Methanol: Oil) }\end{array}$ & $\begin{array}{l}\text { Catalyst } \\
(w t \%)\end{array}$ & $\begin{array}{l}\text { Time } \\
\text { (min) }\end{array}$ & $\begin{array}{l}\text { Yield } \\
\text { (wt\%) }\end{array}$ & $\begin{array}{l}\text { Reusability } \\
\text { (Cycle) }\end{array}$ & Reference \\
\hline Palm & Hydrothermal & 65 & $18: 1$ & 7.5 & 180 & 98.2 & 5 & [81] \\
\hline Sunflower & Ultrasound-dispersion & 60 & $12: 1$ & 4.0 & 120 & 96.5 & $\mathrm{~N} / \mathrm{A}$ & {$[80]$} \\
\hline Sunflower & Impregnation and sono dispersion & 70 & $12: 1$ & 12.0 & $\mathrm{~N} / \mathrm{A}$ & $\mathrm{N} / \mathrm{A}$ & 4 & [69] \\
\hline WCO & Impregnation & 90 & $1: 15$ & 6.0 & 120 & 96.5 & 5 & [70] \\
\hline Palm & Impregnation & 60 & $20: 1$ & 3.0 & 120 & 87.5 & 6 & [71] \\
\hline Sunflower & Metallic citrates decomposition & 60 & $48: 1$ & 2.0 & 240 & 99.0 & $\mathrm{~N} / \mathrm{A}$ & [72] \\
\hline Soybean & Wet impregnation & 70 & $12: 1$ & 8.0 & 360 & 89.3 & 5 & [84] \\
\hline Soybean & $\begin{array}{l}\text { Co-precipitation followed by } \\
\text { impregnation }\end{array}$ & 65 & $13: 1$ & 2.0 & 120 & 95.1 & 4 & [78] \\
\hline Jatropha curcas & Impregnation & 70 & $9: 1$ & 6.0 & 180 & 96.1 & 4 & [73] \\
\hline Waste palm & Impregnation & 65 & $12: 1$ & 6.0 & 360 & 95.4 & $\mathrm{~N} / \mathrm{A}$ & [79] \\
\hline Soybean & Microwave irradiation & 65 & $9: 1$ & 3.0 & 180 & 95.0 & $\mathrm{~N} / \mathrm{A}$ & [67] \\
\hline Palm & Incipient wetness impregnation & 60 & $12: 1$ & 9.0 & 360 & 94.1 & 5 & [82] \\
\hline Crude palm & Wet impregnation & 45 & $12: 1$ & 6.0 & 180 & 97.1 & 3 & [83] \\
\hline
\end{tabular}

$\mathrm{CaO}$ catalysts have few inherent issues such as leaching and diminished stability. The leaching of $\mathrm{CaO}$ catalysts can cause catalyst deactivation. $\mathrm{CaO}$ can be immobilized on a suitable carrier to improve stability and overcome the catalyst weakness. $\mathrm{Al}_{2} \mathrm{O}_{3}$ is one of the bests candidates as a catalyst carrier thanks to its large surface area, fine pore distribution and structural flexibility. $\mathrm{SrO}-\mathrm{CaO}-\mathrm{Al}_{2} \mathrm{O}_{3}$ trimetallic oxide catalyst was reported for the first time. $\mathrm{CaO}$ leaching was greatly decreased and the catalyst stability increased substantially [81]. Porous materials used as carriers for $\mathrm{CaO}$ can boost the stability of the catalyst and the high surface area may lead to superior metal oxide dispersion, and thus, improve their catalysis activity. Bimodal meso-macroporous silica materials were made via the sol-gel method and $\mathrm{CaO}$ was loaded on the developed material by using the incipient wetness impregnation method [82]. The catalyst was applied in the transesterification of palm oil and a FAME yield of $94.2 \%$ was achieved. However, the low rate of dispersion of massive triglycerides through the pores can decrease the activity of the $\mathrm{CaO}$ load on the porous materials.

The wet impregnation method was used to make palm-oil-mill fly-ash-supported $\mathrm{CaO}$ to generate biodiesel from palm oil [83]. Characterization results revealed higher surface area and basic sites for the catalyst compared to the unsupported catalyst. The transesterification process was conducted at $45^{\circ} \mathrm{C}$ reaction temperature, $6.0 \%$ catalyst and 12:1 methanol to oil molar ratio, and $3 \mathrm{~h}$ reaction time. FAME conversion and biodiesel yield of $97.1 \%$ and $79.8 \%$ were obtained when supported and unsupported catalysts were used in the reaction. The wet impregnation method was used to synthesize $\mathrm{CaO}-\mathrm{SnO}_{2}$ catalysts and $89.3 \%$ yield was achieved under reaction time of $6 \mathrm{~h}, 8 \%$ catalyst, the methanol to oil molar ratio of 12:1, and temperature of $343 \mathrm{~K}$ [84].

Activated carbon-supported $\mathrm{CaO}$ was developed and applied in the transesterification of WCO and the process yielded 77.3\% FAME [85] and the optimum reaction conditions were $5.5 \%$ catalyst amount, $170{ }^{\circ} \mathrm{C}$ temperature, $15: 1$ of methanol to oil molar ratio and $2 \mathrm{~h}$ 
and 22 min reaction time. Moreover, nanomaterials of natural or artificial origin, with one dimension of $100 \mathrm{~nm}$ or smaller, have been widely applied in the field of catalysts development for biodiesel production. For example, gold nanoparticles were used as support for $\mathrm{CaO}$ catalysts and the synthesized catalysts showed better catalytic activities [86]. The transesterification catalyzed by these gold nanoparticles-based $\mathrm{CaO}$ catalysts had a high yield ( $\geq 85 \%$ ) after ten cycles of recycling.

\subsection{Seashell and Eggshell Derived CaO Catalysts}

Seashells and eggshells are promising sources for $\mathrm{CaO}$ production for having calcium in their structure, given that utilization of these shells is environmentally friendly and has no detrimental effect on the ecosystem $[87,88]$. CaO-based catalysts were produced from abundant natural $\mathrm{CaCO}_{3}$ origins, including mollusk shells, waste eggshells [89], ostrich eggshells, golden apple snail shells, capiz shell, meretrix shells, Chicoreus brunneus, shell crab shell, and clamshell. $\mathrm{CaCO}_{3}$ obtained from these natural sources can be converted to $\mathrm{CaO}$ by calcination $[15,41,48,90]$. The retrieval of natural $\mathrm{CaO}$ instead of utilizing the synthetic ones is a novel way in catalyst preparation [91]. However, there are limited numbers of articles exploring the utilization of seashells and eggshells as natural, low-cost sources for $\mathrm{CaO}$ production. In this part, seashells and eggshells used for the CaO-based catalyst synthesis are reviewed and summarized in Table 5.

Table 5. Synthesis of seashell-derived $\mathrm{CaO}$ from various sources and the reaction conditions in biodiesel production.

\begin{tabular}{|c|c|c|c|c|c|c|c|}
\hline $\begin{array}{l}\text { Feedstock } \\
\text { (Oil) }\end{array}$ & Catalyst Source & $\begin{array}{l}\text { Temperature } \\
\left({ }^{\circ} \mathrm{C}\right)\end{array}$ & $\begin{array}{l}\text { Molar Ratio } \\
\text { (Methanol: Oil) }\end{array}$ & $\begin{array}{l}\text { Catalyst } \\
(w t \%)\end{array}$ & $\begin{array}{l}\text { Time } \\
(\mathrm{min})\end{array}$ & $\begin{array}{l}\text { Yield } \\
(w t \%)\end{array}$ & Reference \\
\hline Chicken fat & Turritella terebra & 65 & $1: 1$ & 4.0 & 90 & 94.0 & [92] \\
\hline Leather tanning waste & Waste capiz shell & 60 & $6: 1$ & 3.0 & 360 & 93.4 & [93] \\
\hline WCO & Waste oyster shell & 65 & $9: 1$ & 6.0 & 180 & 87.3 & [94] \\
\hline Cotton seed & Waste mollusc shells & 65 & $12: 1$ & 5.0 & 270 & 99.5 & [95] \\
\hline Palm & Waste Mereterix mereterixs & 60 & $30: 1$ & 10.0 & 180 & 95 & [88] \\
\hline WCO & mussel shell & 65 & $9: 1$ & 10.0 & 180 & 89.0 & {$[96]$} \\
\hline WCO & Malleus malleus & 65 & $12: 1$ & 7.5 & 86 & 93.8 & [97] \\
\hline WCO & Donax deltoides & 65 & $63: 8$ & 7.5 & 129 & 96.5 & [98] \\
\hline Chlorella vulgaris biomass & Eggshell & 70 & $10: 1$ & 1.4 & 180 & 92.3 & [99] \\
\hline WCO & Mereterix mereterixs & 60 & $6.0: 1$ & 0.1 & 180 & 89.0 & [100] \\
\hline Palm & Riversnail shell & 65 & $12: 1$ & 1.0 & 90 & $\mathrm{~N} / \mathrm{A}$ & [101] \\
\hline Palm & Mixed seashells & 60 & $30: 1$ & 10.0 & 180 & 96.0 & [102] \\
\hline Castor & Mud clam shell & 60 & $14: 1$ & 3.0 & 120 & 96.7 & [87] \\
\hline Palm & Cyrtopleura costata & 60 & $5: 1$ & 0.1 & 10 & 96.0 & [103] \\
\hline Jatropha curcas & Polymedosaerosa & 25 & $5.2: 1$ & 0.02 & 133 & 98.5 & [104] \\
\hline Palm oil & Waste obtuse horn shell & $\mathrm{N} / \mathrm{A}$ & $12: 1$ & 5.0 & 360 & 86.8 & [105] \\
\hline WCO & Scallop shell & 65 & $6: 1$ & 5.0 & 120 & 86.0 & [106] \\
\hline WCO & Eggshell & 25 & $6: 1$ & 5.8 & 660 & 97.0 & [107] \\
\hline Microalgal & Cyrtopleura costata & 65 & $150: 1$ & 9.0 & 120 & 84.1 & [108] \\
\hline Rubber seeds & Waste cockle shell & $\mathrm{N} / \mathrm{A}$ & $15.7: 1$ & 9.0 & 201 & 88.1 & [109] \\
\hline
\end{tabular}

$\mathrm{CaCO}_{3}$ is converted to $\mathrm{CaO}$ through the calcination process $[101,110,111]$ and a longer calcination time results in a shorter reaction time, which is an important factor in the transesterification process [110]. The yield of transesterification catalyzed by CaO catalyst derived from river snail increased by an increase in time [101]. Turritella terebra was used for $\mathrm{CaO}$ catalyst production. The catalyst was used in the transesterification of chicken fat. A yield of $94.0 \%$ was obtained under the following experimental conditions: $4 \%$ catalyst amount, methanol to oil molar ratio of 1:12 and reaction time of $90 \mathrm{~min}$ [92].

The conversion of waste shells into heterogeneous inorganic catalysts is one of the principal approaches to reducing the amount of waste being disposed of in the landfill and increasing the commercial value of seafood production. $\mathrm{CaO}$ catalyst from waste mollusc shells exhibited better surface structural properties than commercial CaO. FAME yield of 99.5\% was obtained for transesterification of cotton seed oil (reaction conditions-methanol: oil molar ratio 12:1, catalyst amount $5 \%$, reaction temperature $65{ }^{\circ} \mathrm{C}$ for $4.5 \mathrm{~h}$ ) [95]. $\mathrm{CaO}$ catalyst from waste Mereterix mereterixs shells had $95.0 \%$ yield, and and reaction conditions 
for obtaining maximum conversion were $3 \mathrm{~h}$ reaction time, 30:1 of methanol to oil molar ratio, $10.0 \%$ catalyst amount and $60{ }^{\circ} \mathrm{C}$ reaction temperature [102]. Waste mussel shell catalyzed the transesterification of $\mathrm{WCO}$ and $89.0 \%$ yield was obtained after $3 \mathrm{~h}$ with 9:1 methanol to oil molar ratio at $65^{\circ} \mathrm{C}$ [96]. Waste Malleus malleus shells were used for biodiesel production using WCO as feedstock; biodiesel conversion of $93.8 \%$ was achieved by using catalyst concentration of $7.5 \%$, the methanol to oil ratio of $12: 1$ and reaction time of 86.25. CaO catalyst from waste capiz shells had $90.0 \%$ yield after three cycles, and reaction conditions for obtaining maximum conversion were $4 \mathrm{~h}$ reaction time, $6: 1$ of methanol to oil molar ratio, 3.0\% catalyst amount and $60{ }^{\circ} \mathrm{C}$ reaction temperature [93]. Waste oyster shell catalyzed the transesterification of $\mathrm{WCO}$ and $87.3 \%$ yield was obtained after $3 \mathrm{~h}$ with 9:1 methanol to oil molar ratio at $65{ }^{\circ} \mathrm{C}$ [94]. Donax deltoides shells were used as a source of $\mathrm{CaO}$ for biodiesel production using WCO as feedstock; biodiesel conversion of $96.5 \%$ was achieved with a catalyst concentration of $7.5 \%$, the methanol to oil volumetric ratio of $63.8 \%$ and reaction time of $129.3 \mathrm{~min}$ [98]. River snail shell was used as a CaO source to produce biodiesel from palm oil as a feedstock [112,113]. Furthermore, CaO catalysts are produced from mixed shells of Meretrix meretrix, Amusium pleuronectes, Perna viridis, Anadara granosa via dissolution precipitation method and by using $10.0 \%$ catalyst, $96.0 \%$ was achieved up to five cycles [102]. CaO catalyst was synthesized from clamshell and the yield was $96.7 \%$ after five times recycling [87].

The properties of catalysts can change depending on their sources. For example, $\mathrm{CaO}$ catalysts produced from natural dolomitic rocks had a faster conversion rate compared to the catalysts produced via same method from waste mixed seashells [114]. Moreover, reaction conditions, such as higher temperatures can increase catalytic activity, and thus, high yields can be achieved in a shorter period of time. For example, microwave-assisted transesterification catalyzed by Cyrtopleura costata seashell-derived $\mathrm{CaO}$ catalyst resulted in $96.0 \%$ yield in 10 min reaction time [103]. Moreover, basicity also improves the catalytic activity; $98 \%$ yield was obtained when the reaction was catalyzed by barium (Ba) doped $\mathrm{CaO}$ catalysts obtained from waste of Turbonill astriatula seashells [115]. Although Caobased catalyst, similar to other heterogeneous catalysts, can be recycled and reused up to several cycles with maintained yield, their reactivity may diminish after few cycles of reuse. The biodiesel yield decreased from $86.8 \%$ in cycle two to $70 \%$ on the third cycle when $\mathrm{CaO}$ catalysts synthesized from obtuse horn shells catalyzed the reaction [105].

$\mathrm{CaO}$ nanocatalysts from polymedosa erosa seashells were synthesized using calcination, hydration and dehydration methods and were compared with the synthetic one. The transesterification process was performed using Jatropha curcas oil as a non-edible feedstock under the following conditions: reaction time of $133.1 \mathrm{~min}$, at room temperature, and methanol to oil ratio of 5.2:1, resulting in biodiesel yield of $98.5 \%$. In terms of reusability, the catalyst was used up to six cycles and the biodiesel yield was maintained at an average of $95.8 \%$ [104]. WCO and soybean oil were used as a feedstock for transesterification, which led to the FAME yield of $97.0 \%$. Eggshell was used as a catalyst in this study under the reaction time of $11 \mathrm{~h}$, methanol to oil molar ratio of 6:1 at room temperature. The catalyst was used up to five cycles with WCO and ten cycles with fresh soybean oil. It is noteworthy that the less reusability of the catalyst with WCO was due to the negative effect of FFA on the catalyst [107].

Waste cyrtopleura costata was used as $\mathrm{CaO}$ catalyst source to convert the microalgae oil to biodiesel and 84.1\% of FAME yield was obtained at $1 \mathrm{~h}$ reaction time, a 150:1 weight ratio of methanol to oil at $65{ }^{\circ} \mathrm{C}$ [108]. The authors reported that the catalyst was efficient more than three times, showing the FAME yield of more than $65.0 \%$. Waste cockle shells were utilized as a catalyst source and $88.06 \%$ biodiesel yield was obtained by using rubber seed oil as the feedstock [109]. The transesterification was carried out under the following conditions: methanol to oil molar ratio of $15.6: 1$, catalyst amount of $9.0 \%$, and $168 \mathrm{~min}$ reaction time. Snail shells were used as feedstock for the catalyst in biodiesel production and reported a higher yield than when waste cockleshells were used. the author reported that the biodiesel yield obtained was $96.0 \%$ under conditions of methanol to oil molar 
ratio of 9:1, catalyst amount of $10.0 \%$ and at $65^{\circ} \mathrm{C}$ [116]. $\mathrm{CaO}$ was obtained successfully from seashells source through calcination in high temperature. Calcination temperature and calcination time were the most effective parameters influenced on $\mathrm{CaCO}_{3}$ conversion to $\mathrm{CO}_{2}$.

In most of the comparative investigations, natural CaOs obtained from seashells showed higher catalytic activity than synthetic catalysts $[104,106,117]$. It was found that the natural $\mathrm{CaO}$ had more surface area and it had a negligible amount of $\mathrm{Mg}$ and $\mathrm{Sr}$, and due to the basicity of those alkaline metal oxides, the catalytic activity of seashell obtained catalyst increases [106]. The natural source received $\mathrm{CaO}$ showed better catalytic activity due to smaller particle size and larger surface area [87]. In another comparative research, hydrated lime-derived $\mathrm{CaO}$ presented greater surface area and pore volume than the synthetic one. Furthermore, in terms of N2 adsorption isotherms, a small hysteresis loop was identified in hydrated lime-derived $\mathrm{CaO}$, while such structure was not found in commercial $\mathrm{CaO}$ [48]. The preparation of synthetic $\mathrm{CaO}$ would be obtained only by calcination, while the development of $\mathrm{CaO}$ from natural sources needs other steps such as cleaning, drying, washing, dehydration, blending, and calcination. Overall, as there were limited comparative papers, it is hugely suggested to compare the naturally obtained catalyst with the synthetic one.

Characterization is an important feature for studying the spectral and structural characteristics of the catalyst, and numerous methods are used for the characterization of heterogeneous catalysts. However, choosing the best technique relies on the data presented by the methods. The common methods used for characterization are thermogravimetric analysis (TGA), Brunauer Emmet-Teller (BET) surface analyzer, X-ray diffraction (XRD), XRay photoelectron spectroscopy (XPS) and scanning electron microscopy (SEM). TG/DTA analyzer was used to determine the thermal stability of the synthesized zeolite-based catalyst $[35,118]$. BET surface analyser is used to measure the surface area, pore volume and pore diameter of the catalysts. Adsorption and desorption of nitrogen applies in the system to manifest the pore size distribution and surface area of the catalyst. In this technique, to eliminate the water and other polluting materials and let these lines become accessible to be filled with nitrogen molecules, the solid samples are discharged in a vacuum and at temperatures between 50 to $60{ }^{\circ} \mathrm{C}$. Over a wide area, XRD is a common method to characterize the general crystalline material. This method determines the crystalline phases in bulk materials and also verifies their shape and size based on the diffraction peak attributes. Furthermore, the crystalline size of catalysts can be determined from half of the width for a (200) diffraction peak using the Scherrer equation. SEM is conducted to investigate the surface structure of the catalysts after development from seashells to confirm their structure, as well as the surface changes after reusability. Qualitative information regarding the morphology of the samples can be obtained SEM functions by focusing electron beams passing across the sample surface and imaging can be carried at different magnifications and resolutions. XPS is another method for catalyst characterization. This technique is used to determine the chemical and physical changes of catalysts upon exposure to gaseous molecules and upon different thermal treatments. Photo-ionization is applied, and after that, the kinetic energy distribution of emitted photoelectrons is analyzed to approximate the elemental constitution and chemical phase of the elements on the surface. This is obtained by discharging a soft X-ray onto the surface and identifying the energy of the photoelectrons released from areas a few nm (up to 5) from the surface of a sample [119].

\section{Factors Affecting the Transesterification Catalyzed with $\mathrm{CaO}$-Based Catalysts}

Temperature, alcohol to oil molar ratio, catalyst amount, and reaction time are the key parameters that affect the transesterification rate and the FAME conversion. In addition to the key parameters, several specific criteria should be taken into account when using $\mathrm{CaO}$ or $\mathrm{CaO}$-derived catalysts in the reaction, such as catalyst reusability, calcination temperature, total basic sites, water content, use of support for the catalyst, and FFA. The effect of these criteria on the reaction rate and yield are discussed in the subsequent section. 


\subsection{Effect of Catalyst Reusability}

Catalyst reusability is an advantage of heterogeneous catalysts, and most of the alkaline metal oxides have the ability to be used several times. However, such catalysts may change during transesterification. Based on the XRD results, the crystalline structure of the reused catalyst deteriorated after four cycles [115]. The basicity of the catalyst was also diminished. Catalysts were rescued for four cycles, and 90\% FAME yield was maintained [101]. Catalysts obtained from waste seashells with the reusability of up to ten cycles without any apparent loss of performance were reported [120]. However, most of the research reported the reusability of CaO-based catalysts up to five cycles $[87,102,118]$.

\subsection{Effect of Catalyst Loading Amount}

The catalyst loading amount is a critical factor affecting the process and catalyst amount [87]. Biodiesel yield was enhanced with increasing catalyst content from $5.0 \%$ to $10.0 \%$ [121]. On the contrary, the catalyst amount of more than $11 \%$ resulted in troubled mixing due to high viscosity, and hence the yield concentration dropped significantly [41]. Loading high concentrations of the catalysts can make the catalyst less fundamental, which then leads to low catalyst activity [115].

\subsection{Effect of Water Content on Catalytic Activity}

Water exerts various influences on catalytic activity and on the reaction yield. For instance, an increase in water content can increase saponification due to the hydrolysis of triglycerides to FFA [106,122]. The yield of WCO-based biodiesel decreased when water content increased from $0.6 \%$ to $2.5 \%$. The presence of water in methanol, on the other hand, can increase the yield due to the formation of more methoxide anions as a result of water adsorption on the surface of $\mathrm{CaO}$ and hydroxyl groups formation [123]. However, hydration of $\mathrm{CaO}$ before calcination enhanced the catalytic performance [124], and hydrated $\mathrm{CaO}$ elevated the conversion rate and, accordingly, the biodiesel yield [125].

\subsection{Effect of Alcohol to Oil Ratio}

The alcohol-to-oil ratio has more effect on biodiesel yield than the catalyst loading amount yield $[109,126]$. An increase of yield from $55.5 \%$ to $88.1 \%$ was observed when the alcohol-to-oil ratio was increased stepwise, while the excessive rise in the alcohol-to-oil ratio decreased due to a decreased interaction of catalyst and oil $[109,126]$. Consequently, a higher amount of alcohol could minimize the interaction of the catalyst and oil resulting in a lower biodiesel yield. From the other point of view, the influence of impurity of source material on catalytic activity and the effect of storage conditions by FTIR and TGA were respectively studied [118,127]. In another study, the influence of adding a co-solvent on FAME yield and reaction kinetics was examined. By applying a suitable co-solvent during the biodiesel production, the reaction time and biodiesel production expenses could be reduced greatly. Thus, alcohol-to-oil molar ratio could directly impact the biodiesel yield greatly [48].

\subsection{Effect of Support}

Using catalyst supports can boost catalytic activity by stabilizing the catalyst and decreasing the leaching issues of $\mathrm{CaO}$ catalysts. $\mathrm{CaO}$ supported on $\mathrm{MgO}$ had a better catalytic activity than an unsupported catalyst due to improved basicity and increased surface area $[63,117]$. Scallop shell supported with $\mathrm{MgCO}_{3}$ was synthesized as a catalyst with a smaller crystalline size and a better activity [127]. CaO supported with Tin oxide $\left(\mathrm{CaO}-\mathrm{SnO}_{2}\right)$ had a better catalytic activity due to the improved stability as a result of supporting the catalyst [84]. Thus, using support for CaO-based catalysts can overcome their leaching problem and improve their activity in the process of biodiesel production. 


\subsection{Effect of FFA on Catalytic Activity}

$\mathrm{CaO}$-based catalysts can be affected by FFA, and oils with low FFA content serve as better feedstocks for CaO-catalyzed transesterification [128]. The presence of FFA makes the catalyst less active and affects the catalyst reusability. A high concentration of FFA in WCO exerted a negative influence on catalyst reusability and resulted in a decrease in catalyst activity after the fifth cycle, while the same catalyst with fresh soybean oil was active up to ten cycles [118].

\subsection{Effect of Basic Sites}

Basicity has an important role in catalyst productivity which can contribute to biodiesel production [115]. The higher the basicity of the catalyst, the higher the catalyst activity [129]. There are different ways to improve the basicity of the catalyst. Ultrasonic assisted transesterification is an efficient method when using $\mathrm{CaO}$ as a catalyst as it can crush the catalyst into a smaller part which leads to increased basic sites. Basic sites have the main role in $\mathrm{CaO}$ efficiency as a catalyst, therefore increased basic sites improves the transesterification efficiency. Further, increased basicity reduces the time needed for oil conversion to biodiesel [51]. Further, using zeolite as support can provide more surface area for the catalyst as a carrier which enhances the basicity of the catalyst. NaY, KL, and NaZSM- 5 zeolites were modified by $\mathrm{CaO}$ via microwave irradiation to be used in the transesterification of soybean oil with methanol. The supported $\mathrm{CaO}$ catalyst revealed more catalytic activity than the pure $\mathrm{CaO}$. The enhanced activity was due to the increase of BET values and basicity after loading on NaY zeolite [67]. Decreased catalytic activity, on the other hand, can be attributed to the blockage of basic sites due to excess Ba loading and the subsequent obstruction would pose difficulty to the diffusion of reactants throughout the catalyst [115]. However, catalyst activity does not solely rely on basic sites of the catalyst and other parameters such as feedstock used, time, temperature, etc., can affect the yield [130].

\subsection{Effect of Calcination Temperature}

The calcination temperature is a significant factor affecting the efficiency of the catalyst. Calcination at high temperatures increases the surface area and porosity and activates the $\mathrm{CaO}-b a s e d$ catalyst, and therefore results in a better catalytic effect. River snail-based $\mathrm{CaO}$, produced at longer calcination temperatures, showed a better catalytic activity and higher yields were achieved.

Surface area, total pore volume, and mean pore diameter of the sample, however, will decrease by increasing the calcination temperatures to above $800^{\circ} \mathrm{C}$. It was found that the optimum calcination temperature was $600^{\circ} \mathrm{C}$, and the catalyst activity was affected by a decrease in surface area and porosity as a result of calcination at elevated temperatures [131]. The source of calcium was mixed shells of Meretrix meretrix, Amusium pleuronectes, Perna viridis, Anadara granosa. Calcium- zinc and aluminum compounds was prepared via the dissolution precipitation method and subsequently applied in transesterification and the higher calcination temperature made the catalyst more active and basic [102].

In summary, there are different criteria affecting the catalyst performance, which should be paid attention to. These criteria can significantly affect the FAME yield. Optimization is still a matter of concern while producing biodiesel. The response surface methodology RSM and central composite design (CCD), Box-Behnken factorial design and Analysis of variance (ANOVA) are general tools for optimization. In the following section, the most common reactors in use for biodiesel production by using heterogeneous catalysts have been reviewed.

\section{Reactors for Heterogeneously Catalyzed Transesterification}

The heterogeneously catalyzed transesterification process, including the $\mathrm{CaO}$-catalyzed reactions, are typically conducted in batch stirred reactors due to their simple process. However, the implementation of these reactors leads to an increase in capital investments, as they require a large reactor volume. Therefore, a continuous process can overcome this problem 
as continuous reactors can work with smaller volumes. The packed bed reactor (PBR), trickle-bed reactor (TBR), and packed bed membrane reactor are common types of reactors used in batch and continuous processes catalyzed by heterogeneous catalysis [132-134].

\subsection{The Packed Bed Reactor (PBR)}

PBR consists of a water-jacketed stainless-steel section. The column is packed with heterogeneous catalysts and oil and methanol will be permeated into the process by utilizing two separate raw material pumps. Blending and preheating of the reactants happens in a blending tank and the blend will be then nourished to the channel of the reactor by a pump. The reaction temperature will be managed by a heater to keep a steady temperature and the temperature indicators and pressure gauges are used to observe the system temperature and pressure. Purification is carried out by reducing the pressure distillation to eliminate the overabundance of methanol and water produced through the reaction. A methanol recovery unit does continuous distillation with a condenser and a heater. Methanol, because of having a low melting point, could be recovered via sequential processes of evaporation and distillation. The permeate stream comprising biodiesel, methanol, and glycerol will be collected [135]. Moreover, by applying a solid alkaline catalyst in a continuous flow PBR, both separation of catalyst and co-production of high pure glycerol processes were made easier, and hence it leads to a decrease in production costs and feasibility of catalysts reuse. A schematic diagram of PBR is shown in Figure 3.

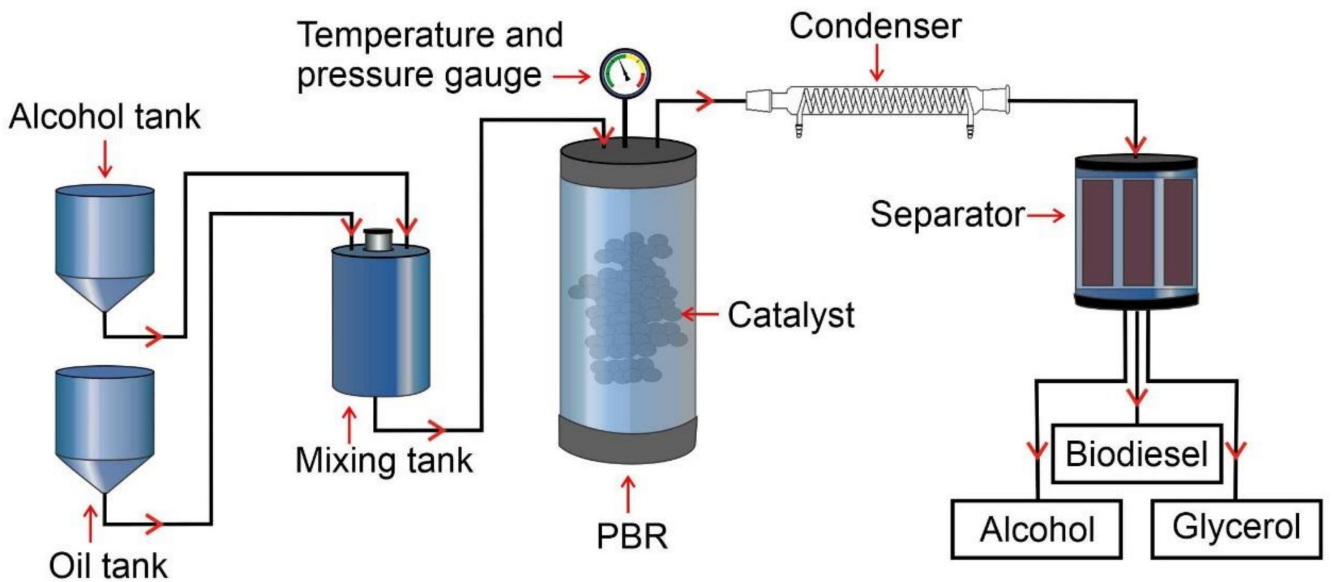

Figure 3. Schematic of packed bed reactor.

\subsection{The Trickle-Bed Reactor (TBR)}

In a TBR, syringe pumps are used to nourish methanol and oil into the reactor. Complete evaporation of methanol occurs in the heated part at the lowest part of the reactor, and its vapor will be moved throughout the catalyst bed. A condenser is implemented to recover the unreacted methanol. The oil is nourished through a single tube and is distributed on the catalyst bed. FAME, glycerol and unreacted oil are recovered in the product reservoir. The catalyst particles will be assembled into the base of the reactor and glass beads of the same diameter will be charged into the remainder of the reactor. An electric heater is used to heat the TBR to a designated temperature. The reaction product is then centrifuged. Deionized water will be used to rinse the upper ester layer, and the product is separated by centrifugation [133]. A schematic diagram of TBR is shown in Figure 4. 


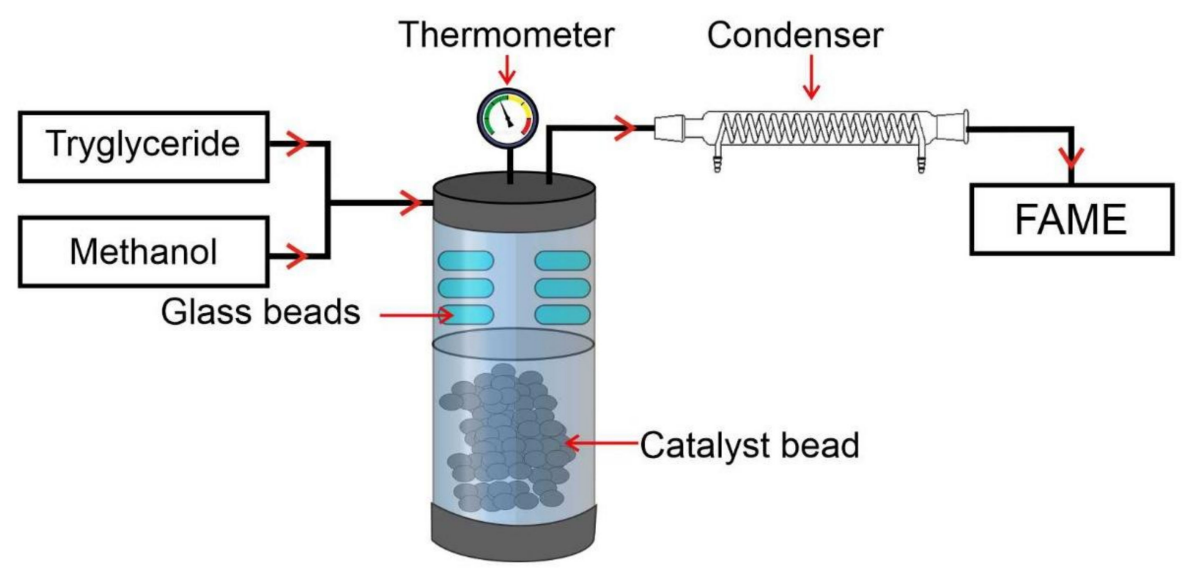

Figure 4. Schematic of trickle-bed reactor.

\subsection{The Packed Bed Membrane Reactor (PBMR)}

This reactor is designed to discharge the product selectively, adjust the addition of reactants to the process, and enhance the catalyst and reactants interactions [134]. Methanol molecules, biodiesel, and glycerol can pass through the membrane. Methanol should be recycled and returned to the reaction, as it is one of the essential factors for value adding to the process; thus, this reactor has a simple and efficient methanol recovery unit. This system is dependent upon continuous distillation, including a three-neck round bottom flask, thermometer and condenser. Biodiesel, methanol, and glycerol are leached through and collected in the three-neck round bottom container. Immediate methanol evaporation occurs as a result of the high temperature of the oil bath. Methanol is continuously evaporated due to its lower boiling point, followed by distillation and returning to the process to reduce its depletion. A schematic diagram of PBMR is shown in Figure 5.

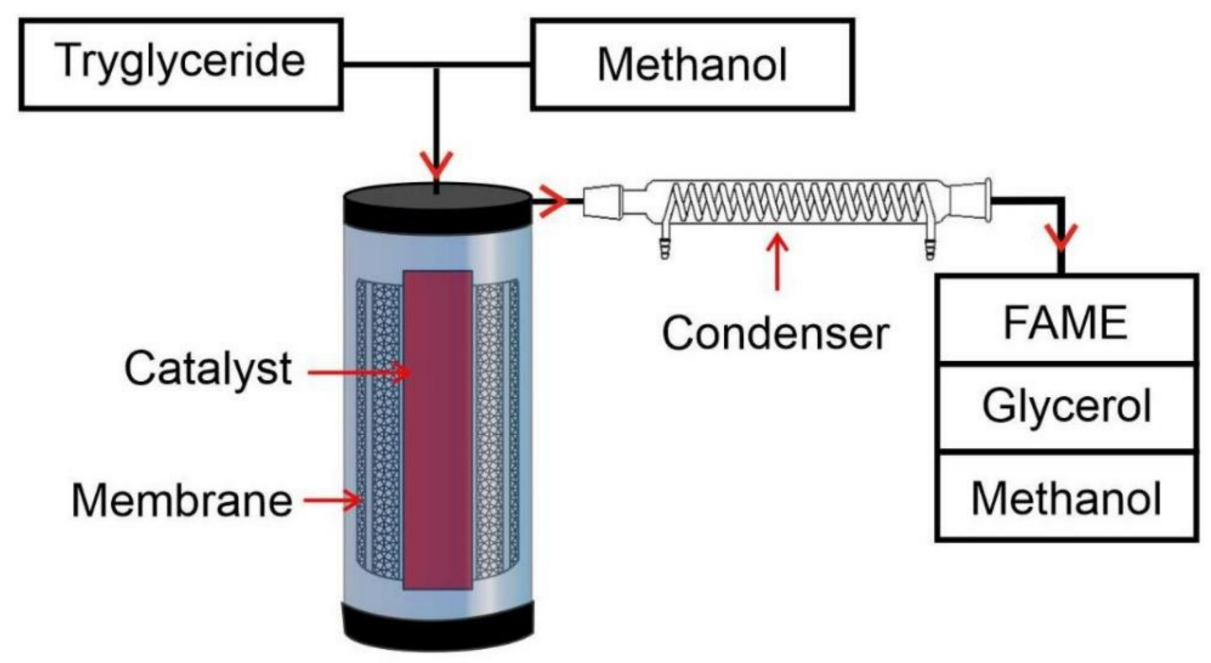

Figure 5. Schematic of packed bed membrane reactor.

\section{Ultrasonic-Assisted and Microwave-Assisted Transesterification}

\subsection{Ultrasonic-Assisted Transesterification}

The ultrasonic process implementing sound wave energy was introduced as an effective method for heterogeneous catalyzed transesterification. This method influences the reaction by making and collapsing micro-bubbles. Reduced reaction time, increased reaction rate, low catalyst consumption rate and less methanol demand and improved yield are unique features of this technology, which makes it more applicable. This method leads to a high yield of biodiesel as a result of a natural mixing of oil and alcohol compared to the conventional methods. Moreover, ultrasonic irradiation can break the catalyst into 
smaller parts [25,38]. The yield of ultrasonic-assisted transesterification $(20 \mathrm{kHz}$ ultrasonic cavitation) at the presence of $\mathrm{CaO}, \mathrm{SrO}$ and $\mathrm{BaO}$ catalysts and palm oil in 60 min increased from $5.5 \%$ to $77.3 \%(\mathrm{CaO}), 48.2 \%$ to $95.2 \%(\mathrm{SrO})$, and $67.3 \%$ to $95.2 \%$ for $\mathrm{BaO}$ [136]. Further, calcium methoxide catalyst catalyzed the transesterification of soybean oil at $65^{\circ} \mathrm{C}$ with $9: 1$ alcohol-to-oil molar ratio, and the biodiesel yield of more than $90.0 \%$ was achieved [41].

\subsection{Microwave-Assisted Transesterification}

Microwave-assisted technology is based upon the application of electromagnetic waves between infrared radiation and radio frequencies of $30 \mathrm{GHz}$ to $300 \mathrm{MHz}$. Shorter reaction-time as a result of rapid heating and increased biodiesel yield are the main features of this method. The radiation affects the molecular movement but not the molecular structure. Therefore, biodiesel obtained through this technique has the same characteristic as the biodiesel obtained with the aid of conventional methods [25,38]. Microwaveassisted transesterification was carried out in a short reaction time of $10 \mathrm{~min}$ and palm oil with the methanol to oil molar ratio of 5:1 was successfully converted to biodiesel (yield of $96.0 \%$ ) [103].

\section{Challenges and Prospects}

Despite the benefits of the heterogeneous catalyst over the homogeneous catalyst, there are still some limitations to applying these catalysts. The main limitation is that these catalysts can only be used with triglycerides having less than $0.5 \%$ of FFA as they make the catalyst neutral. Leaching of the active phase is another challenge with these catalysts, which reduces the efficiency of the catalyst after several cycles. Further, the product is contaminated due to catalyst leaching. Catalyst deactivation due to water and $\mathrm{CaO}$ adsorption in intact contact with air is another challenge. Another challenge with $\mathrm{CaO}$ derived catalysts is their tendency to bind to glycerol during the reaction and the formed complex of Ca-Gly is less active in terms of catalysis than the $\mathrm{CaO}$ [137].

Calcium-rich catalysts have a significant disadvantage of mass transfer resistance between reactants and products, which leads to a costly production process and prolonged reaction time [138]. Methods, such as ultrasound-assisted and microwave-assisted transesterification are conducted to reduce the mass transfer resistance, which results in less energy consumption and shorter reaction-times $[139,140]$. Further, to commercialize these heterogeneous alkali catalysts in the future, more fortifying systems need to be generated.

The elimination of $\mathrm{CaO}$ from reaction requires more purification steps, which results in a large amount of wastewater. Additionally, $\mathrm{CaO}$ exposure to air may cause a problem in its catalytic activity due to the chemisorption of $\mathrm{CO}_{2}$ and $\mathrm{H}_{2} \mathrm{O}$. It is recommended to store the catalyst in a desiccator to reduce the catalyst exposure to air during the experiment is inevitable. Therefore, measures need to be taken to avoid catalyst air exposure or at least minimize it. Moreover, CaO-based catalysts can only be used with triglycerides having less than $0.5 \%$ FFA that increase the cost of biodiesel production. Hence, the pretreatment step is required before applying a $\mathrm{CaO}$-based catalyst to remove the FFA, since high FFA inactivates the $\mathrm{CaO}$-based catalyst.

Therefore, as $\mathrm{CaO}$-based catalysts require specific considerations, in terms of leaching, exposure to air and mass transfer resistance, efficient design of these catalysts are very important to improve the biodiesel yield. There are some methods to make these catalysts more efficient; to mix them with other materials, such as $\mathrm{MgO}-\mathrm{CaO}, \mathrm{CaO}-\mathrm{SiO}_{2}, \mathrm{CaO}-\mathrm{ZnO}$ to overcome the leaching problems. Further, using supports such as zeolite can minimize the leaching. Therefore, future work is essential to find more compounds to make $\mathrm{CaO}$ derived catalysts more applicable for use at an industrial scale.

\section{Conclusions}

Biodiesel has been categorized within sustainable fuels due to its distinctive benefits such as being non-toxic, biodegradable, renewable, and eco-friendly. Heterogeneous catalysts have become a focus of attention recently as they are able to avoid the problems 
caused by the use of homogeneous catalysts, such as elongated separation and purification stages, and thus, avoids the longer reaction time and generation of wastewater. Among heterogeneous catalysts, calcium oxide has gained much attention due to its reasonable price, low solubility in methanol, low toxicity, and high availability from natural resources. Among these aforementioned catalysts (such as pure, supported, mixed oxides), seashell derived calcium oxide catalysts are environmentally friendly and have no detrimental effect on the ecosystem. The large-scale application of those wastes will bring economic advantages to the calcium oxide waste materials and make promising catalysts. However, the obtained catalysts are not stable and suffer from leaching problems during the reaction. The preparation of effective and catalytically stable calcium oxide catalysts is still a significant difficulty. Therefore, a continuous attempt is required to modify the technology in order to improve the sustainable biodiesel production and reduce the costs.

Author Contributions: Conceptualization, H.M. and H.C.O; validation, Z.A., H.H.M. and M.M.; formal analysis, H.M. and C.H.S.; investigation, Z.A. and C.H.S.; resources, H.C.O.; data curation, H.M. and T.M.Y.K.; writing-original draft preparation, H.M.; writing—review and editing, H.M., Z.A. and H.C.O.; visualization, H.H.M., I.A.B., and M.M.; supervision, H.C.O.; funding acquisition, I.A.B. All authors have read and agreed to the published version of the manuscript.

Funding: Deanship of Scientific Research at King Khalid University for funding this work through research groups program under grant number (R.G.P.1/251/42).

Institutional Review Board Statement: Not applicable.

Informed Consent Statement: Not applicable.

Data Availability Statement: Not applicable.

Acknowledgments: The authors extend their appreciation to the Deanship of Scientific Research at King Khalid University for funding this work through research groups program under grant number (R.G.P.1/251/42). The authors also acknowledge the contribution of the research strategy fund of the Faculty of Engineering \& IT, University of Technology Sydney, Australia.

Conflicts of Interest: The authors declare no conflict of interest.

\section{References}

1. Amini, Z.; Ong, H.C.; Harrison, M.D.; Kusumo, F.; Mazaheri, H.; Ilham, Z. Biodiesel production by lipase-catalyzed transesterification of Ocimum basilicum L. (sweet basil) seed oil. Energy Convers. Manag. 2017, 132, 82-90. [CrossRef]

2. Muhammad, G.; Alam, A.; Mofijur, M.; Jahirul, M.; Lv, Y.; Xiong, W.; Ong, H.C.; Xu, J. Modern developmental aspects in the field of economical harvesting and biodiesel production from microalgae biomass. Renew. Sustain. Energy Rev. 2021, 135, 110209. [CrossRef]

3. Jeffry, L.; Ong, M.Y.; Nomanbhay, S.; Mofijur, M.; Mubashir, M.; Show, P.L. Greenhouse gases utilization: A review. Fuel 2021, 301, 121017. [CrossRef]

4. Doh, J.; Budhwar, P.; Wood, G. Long-term energy transitions and international business: Concepts, theory, methods, and a research agenda. J. Int. Bus. Stud. 2021, 1-20.

5. York, R.; Bell, S.E. Energy transitions or additions?: Why a transition from fossil fuels requires more than the growth of renewable energy. Energy Res. Soc. Sci. 2019, 51, 40-43. [CrossRef]

6. Electricity in the United States; U.S Energy Information Administration: Washington, DC, USA, 2021.

7. Thanh, L.T.; Okitsu, K.; Van Boi, L.; Maeda, Y. Catalytic Technologies for Biodiesel Fuel Production and Utilization of Glycerol: A Review. Catalysts 2012, 2, 191-222. [CrossRef]

8. Liew, R.K.; Nam, W.L.; Chong, M.Y.; Phang, X.Y.; Su, M.H.; Yek, P.N.Y.; Ma, N.L.; Cheng, C.K.; Chong, C.T.; Lam, S.S. Oil palm waste: An abundant and promising feedstock for microwave pyrolysis conversion into good quality biochar with potential multi-applications. Process. Saf. Environ. Prot. 2018, 115, 57-69. [CrossRef]

9. Waldron, K.W. Advances in Biorefineries: Biomass and Waste Supply Chain Exploitation; Elsevier: Amsterdam, The Netherlands, 2014.

10. Konur, O. Biodiesel Fuels: Science, Technology, Health, and Environment; CRC Press: Boca Raton, FL, USA, 2021.

11. Mofijur, M.; Masjuki, H.H.; Kalam, M.A.; Atabani, A.E. Evaluation of biodiesel blending, engine performance and emissions characteristics of Jatropha curcas methyl ester: Malaysian perspective. Energy 2013, 55, 879-887. [CrossRef]

12. Mofijur, M.; Masjuki, H.H.; Kalam, M.A.; Atabani, A.E.; Fattah, I.M.R.; Mobarak, H.M. Comparative evaluation of performance and emission characteristics of Moringa oleifera and Palm oil based biodiesel in a diesel engine. Ind. Crop. Prod. 2014, 53, 78-84. [CrossRef] 
13. Silitonga, A.; Masjuki, H.; Mahlia, T.; Ong, H.; Chong, W.; Boosroh, M. Overview properties of biodiesel diesel blends from edible and non-edible feedstock. Renew. Sustain. Energy Rev. 2013, 22, 346-360. [CrossRef]

14. Hazrat, M.A.; Rasul, M.G.; Mofijur, M.; Khan, M.M.K.; Djavanroodi, F.; Azad, A.K.; Bhuiya, M.M.K.; Silitonga, A. A Mini Review on the Cold Flow Properties of Biodiesel and its Blends. Front. Energy Res. 2020, 8. [CrossRef]

15. Mazaheri, H.; Ong, H.C.; Masjuki, H.; Amini, Z.; Harrison, M.D.; Wang, C.-T.; Kusumo, F.; Alwi, A. Rice bran oil based biodiesel production using calcium oxide catalyst derived from Chicoreus brunneus shell. Energy 2018, 144, 10-19. [CrossRef]

16. Hazrat, M.A.; Rasul, M.G.; Khan, M.M.K.; Mofijur, M.; Ahmed, S.F.; Ong, H.C.; Vo, D.-V.N.; Show, P.L. Techniques to improve the stability of biodiesel: A review. Environ. Chem. Lett. 2021, 19, 2209-2236. [CrossRef]

17. Zhou, S.; Liu, L.; Wang, B.; Xu, F.; Sun, R.C. Biodiesel preparation from transesterification of glycerol trioleate catalyzed by basic ionic liquids. Chin. Chem. Lett. 2012, 23, 379-382. [CrossRef]

18. Marwaha, A.; Dhir, A.; Mahla, S.K.; Mohapatra, S.K. An overview of solid base heterogeneous catalysts for biodiesel production. Catal. Rev. 2018, 60, 594-628. [CrossRef]

19. Ling, J.S.J.; Tan, Y.H.; Mubarak, N.M.; Kansedo, J.; Saptoro, A.; Nolasco-Hipolito, C. A review of heterogeneous calcium oxide based catalyst from waste for biodiesel synthesis. SN Appl. Sci. 2019, 1, 1-8. [CrossRef]

20. Lukić, I.; Kesić, Ž.; Zdujić, M.; Skala, D. Synthesis of calcium oxide based catalysts for biodiesel production. In Physical Chemistry 2018, Proceedings of the 14th International Conference on Fundamental and Applied Aspects of Physical Chemistry, Belgrade, Serbia, 24-28 September 2018; Society of Physical Chemists of Serbia: Belgrade, Serbia, 2018; Volume 1.

21. Aghbashlo, M.; Peng, W.; Tabatabaei, M.; Kalogirou, S.A.; Soltanian, S.; Hosseinzadeh-Bandbafha, H.; Mahian, O.; Lam, S.S. Machine learning technology in biodiesel research: A review. Prog. Energy Combust. Sci. 2021, 85, 100904. [CrossRef]

22. Ong, H.C.; Masjuki, H.; Mahlia, T.M.I.; Silitonga, A.; Chong, W.; Leong, K. Optimization of biodiesel production and engine performance from high free fatty acid Calophyllum inophyllum oil in CI diesel engine. Energy Convers. Manag. 2014, 81, 30-40. [CrossRef]

23. Abbaszaadeh, A.; Ghobadian, B.; Omidkhah, M.R.; Najafi, G. Current biodiesel production technologies: A comparative review. Energy Convers. Manag. 2012, 63, 138-148. [CrossRef]

24. Silitonga, A.; Ong, H.; Masjuki, H.; Mahlia, T.M.I.; Chong, W.; Yusaf, T.F. Production of biodiesel from Sterculia foetida and its process optimization. Fuel 2013, 111, 478-484. [CrossRef]

25. Saifuddin, N.; Samiuddin, A.; Kumaran, P. A Review on Processing Technology for Biodiesel Production. Trends Appl. Sci. Res. 2015, 10, 1-37. [CrossRef]

26. Tahvildari, K.; Chitsaz, H.R.; Mozaffarinia, P. Heterogeneous Catalytic Modified Process in the Production of Biodiesel from Sunflower Oil, Waste Cooking Oil and Olive Oil by Transesterification Method. Acad. Res. Int. 2014, 5, 60.

27. Ong, H.C.; Milano, J.; Silitonga, A.S.; Hassan, M.H.; Shamsuddin, A.H.; Wang, C.-T.; Mahlia, T.M.I.; Siswantoro, J.; Kusumo, F.; Sutrisno, J. Biodiesel production from Calophyllum inophyllum-Ceiba pentandra oil mixture: Optimization and characterization. J. Clean. Prod. 2019, 219, 183-198. [CrossRef]

28. Atabani, A.; Silitonga, A.; Ong, H.; Mahlia, T.M.I.; Masjuki, H.; Badruddin, I.A.; Fayaz, H. Non-edible vegetable oils: A critical evaluation of oil extraction, fatty acid compositions, biodiesel production, characteristics, engine performance and emissions production. Renew. Sustain. Energy Rev. 2013, 18, 211-245. [CrossRef]

29. Chhetri, A.B.; Tango, M.S.; Budge, S.M.; Watts, K.C.; Islam, M.R. Non-Edible Plant Oils as New Sources for Biodiesel Production. Int. J. Mol. Sci. 2008, 9, 169-180. [CrossRef]

30. Amini, Z.; Ilham, Z.; Ong, H.C.; Mazaheri, H.; Chen, W.-H. State of the art and prospective of lipase-catalyzed transesterification reaction for biodiesel production. Energy Convers. Manag. 2017, 141, 339-353. [CrossRef]

31. Degfie, T.A.; Mamo, T.T.; Mekonnen, Y.S. Optimized Biodiesel Production from Waste Cooking Oil (WCO) using Calcium Oxide (CaO) Nano-catalyst. Sci. Rep. 2019, 9, 18982. [CrossRef]

32. Mofijur, M.; Siddiki, S.Y.A.; Shuvho, B.A.; Djavanroodi, F.; Fattah, I.R.; Ong, H.C.; Chowdhury, M.; Mahlia, T. Effect of nanocatalysts on the transesterification reaction of first, second and third generation biodiesel sources-A mini-review. Chemosphere 2021, 270, 128642. [CrossRef]

33. Koberg, M.; Gedanken, A. New and Future Developments in Catalysis. Chapter 9. Using Microwave Radiation and SrO as a Catalyst for the Complete Conversion of Oils, Cooked Oils, and Microalgae to Biodiesel; Elsevier Inc.: Amsterdam, The Netherlands, 2013.

34. Thangaraj, B.; Solomon, P.R.; Muniyandi, B.; Ranganathan, S.; Lin, L. Catalysis in biodiesel production-A review. Clean Energy 2018, 3, 2-23. [CrossRef]

35. Hassani, M.; Najafpour, G.D.; Mohammadi, M.; Rabiee, M. Preparation, characterization and application of zeolite-based catalyst for production of biodiesel from waste cooking oil. J. Sci. Ind. Res. 2014, 73, 129-133.

36. Endalew, A.K.; Kiros, Y.; Zanzi, R. Heterogeneous catalysis for biodiesel production from Jatropha curcas oil (JCO). Energy 2011, 36, 2693-2700. [CrossRef]

37. Leung, D.Y.; Wu, X.; Leung, M. A review on biodiesel production using catalyzed transesterification. Appl. Energy 2010, 87, 1083-1095. [CrossRef]

38. Lam, M.K.; Lee, K.T.; Mohamed, A.R. Homogeneous, heterogeneous and enzymatic catalysis for transesterification of high free fatty acid oil (waste cooking oil) to biodiesel: A review. Biotechnol. Adv. 2010, 28, 500-518. [CrossRef]

39. Lee, A.F.; Bennett, J.A.; Manayil, J.C.; Wilson, K. Heterogeneous Catalysis for Sustainable Biodiesel Production via Esterification and Transesterification. Chem. Soc. Rev. 2014, 43, 7887-7916. [CrossRef] 
40. Xue, W.; Zhou, Y.-C.; Song, B.-A.; Shi, X.; Wang, J.; Yin, S.-T.; Hu, D.-Y.; Jin, L.-H.; Yang, S. Synthesis of biodiesel from Jatropha curcas L. seed oil using artificial zeolites loaded with CH3COOK as a heterogeneous catalyst. Nat. Sci. 2009, 1, 55-62. [CrossRef]

41. Deshmane, V.G.; Adewuyi, Y.G. Synthesis and kinetics of biodiesel formation via calcium methoxide base catalyzed transesterification reaction in the absence and presence of ultrasound. Fuel 2013, 107, 474-482. [CrossRef]

42. Marinković, D.; Stanković, M.V.; Veličković, A.V.; Avramović, J.M.; Miladinović, M.R.; Stamenković, O.O.; Veljković, V.B.; Jovanović, D.M. Calcium oxide as a promising heterogeneous catalyst for biodiesel production: Current state and perspectives. Renew. Sustain. Energy Rev. 2016, 56, 1387-1408. [CrossRef]

43. Alonso, D.M.; Vila, F.; Mariscal, R.; Ojeda, M.; Granados, M.L.; Santamaría-González, J. Relevance of the physicochemical properties of $\mathrm{CaO}$ catalysts for the methanolysis of triglycerides to obtain biodiesel. Catal. Today 2010, 158, 114-120. [CrossRef]

44. Wang, J.-X.; Chen, K.-T.; Wu, J.-S.; Wang, P.-H.; Huang, S.-T.; Chen, C.-C. Production of biodiesel through transesterification of soybean oil using lithium orthosilicate solid catalyst. Fuel Process. Technol. 2012, 104, 167-173. [CrossRef]

45. Hebbar, H.H.; Math, M.C.; Yatish, K. Optimization and kinetic study of CaO nano-particles catalyzed biodiesel production from Bombax ceiba oil. Energy 2018, 143, 25-34. [CrossRef]

46. Devaraj, K.; Veerasamy, M.; Aathika, S.; Mani, Y.; Thanarasu, A.; Dhanasekaran, A.; Subramanian, S. Study on effectiveness of activated calcium oxide in pilot plant biodiesel production. J. Clean. Prod. 2019, 225, 18-26. [CrossRef]

47. Badnore, A.U.; Jadhav, N.L.; Pinjari, D.V.; Pandit, A.B. Efficacy of newly developed nano-crystalline calcium oxide catalyst for biodiesel production. Chem. Eng. Process. Process. Intensif. 2018, 133, 312-319. [CrossRef]

48. Roschat, W.; Siritanon, T.; Yoosuk, B.; Promarak, V. Biodiesel production from palm oil using hydrated lime-derived CaO as a low-cost basic heterogeneous catalyst. Energy Convers. Manag. 2016, 108, 459-467. [CrossRef]

49. Maneerung, T.; Kawi, S.; Dai, Y.; Wang, C.-H. Sustainable biodiesel production via transesterification of waste cooking oil by using $\mathrm{CaO}$ catalysts prepared from chicken manure. Energy Convers. Manag. 2016, 123, 487-497. [CrossRef]

50. Aghabarari, B.; Martinez-Huerta, M. Biodiesel Production Using Calcined Waste Filter Press Cake from a Sugar Manufacturing Facility as a Highly Economic Catalyst. J. Am. Oil Chem. Soc. 2016, 93, 773-779. [CrossRef]

51. Korkut, I.; Bayramoglu, M. Ultrasound assisted biodiesel production in presence of dolomite catalyst. Fuel 2016, 180, 624-629. [CrossRef]

52. Poosumas, J.; Ngaosuwan, K.; Quitain, A.T.; Assabumrungrat, S. Role of ultrasonic irradiation on transesterification of palm oil using calcium oxide as a solid base catalyst. Energy Convers. Manag. 2016, 120, 62-70. [CrossRef]

53. Kouzu, M.; Kasuno, T.; Tajika, M.; Sugimoto, Y.; Yamanaka, S.; Hidaka, J. Calcium oxide as a solid base catalyst for transesterification of soybean oil and its application to biodiesel production. Fuel 2008, 87, 2798-2806. [CrossRef]

54. Khalifeh, R.; Esmaeili, H. Biodiesel production from goat fat using calcium oxide nanocatalyst and its combination with diesel fuel to improve fuel properties. Int. J. Sustain. Eng. 2020, 1-10. [CrossRef]

55. Tang, Y.; Yang, Y.; Liu, H.; Yan, T.; Zhang, Z. Preparation of nano-CaO and catalyzing tri-component coupling transesterification to produce biodiesel. Inorg. Nano Met. Chem. 2020, 50, 501-507. [CrossRef]

56. George, P.A.O.; Eras, J.J.C.; Gutierrez, A.S.; Hens, L.; Vandecasteele, C. Residue from Sugarcane Juice Filtration (Filter Cake): Energy Use at the Sugar Factory. Waste Biomass Valorization 2010, 1, 407-413. [CrossRef]

57. Teo, S.H.; Rashid, U.; Choong, S.T.; Taufiq-Yap, Y.H. Heterogeneous calcium-based bimetallic oxide catalyzed transesterification of Elaeis guineensis derived triglycerides for biodiesel production. Energy Convers. Manag. 2017, 141, 20-27. [CrossRef]

58. Foroutan, R.; Mohammadi, R.; Esmaeili, H.; Bektashi, F.M.; Tamjidi, S. Transesterification of waste edible oils to biodiesel using calcium oxide@magnesium oxide nanocatalyst. Waste Manag. 2020, 105, 373-383. [CrossRef] [PubMed]

59. Liu, Y.; Zhang, P.; Fan, M.; Jiang, P. Biodiesel production from soybean oil catalyzed by magnetic nanoparticle $\mathrm{MgFe}_{2} \mathrm{O}_{4} @ \mathrm{CaO}$. Fuel 2016, 164, 314-321. [CrossRef]

60. Fan, M.; Liu, Y.; Zhang, P.; Jiang, P. Blocky shapes Ca-Mg mixed oxides as a water-resistant catalyst for effective synthesis of biodiesel by transesterification. Fuel Process. Technol. 2016, 149, 163-168. [CrossRef]

61. Lee, H.V.; Juan, J.C.; Hin, T.-Y.Y.; Ong, H.C. Environment-Friendly Heterogeneous Alkaline-Based Mixed Metal Oxide Catalysts for Biodiesel Production. Energies 2016, 9, 611. [CrossRef]

62. Syamsuddin, Y.; Murat, M.; Hameed, B. Synthesis of fatty acid methyl ester from the transesterification of high- and low-acidcontent crude palm oil (Elaeis guineensis) and karanj oil (Pongamia pinnata) over a calcium-lanthanum-aluminum mixed-oxides catalyst. Bioresour. Technol. 2016, 214, 248-252. [CrossRef]

63. Kesić, Ž.; Lukić, I.; Zdujić, M.; Jovalekić, Č.; Veljković, V.; Skala, D. Assessment of $\mathrm{CaTiO}_{3}, \mathrm{CaMnO}_{3}, \mathrm{CaZrO}_{3}$ and Ca $2 \mathrm{Fe}_{2} \mathrm{O}_{5}$ perovskites as heterogeneous base catalysts for biodiesel synthesis. Fuel Process. Technol. 2016, 143, 162-168. [CrossRef]

64. Jindapon, W.; Kuchonthara, P.; Ngamcharussrivichai, C. Biodiesel production over Ca, Zn, and Al mixed compounds in fixedbed reactor: Effects of premixing catalyst extrudates with methanol, oil, and fatty acid methyl esters. Fuel Process. Technol. 2016, 148, 67-75. [CrossRef]

65. Naveenkumar, R.; Baskar, G. Biodiesel production from Calophyllum inophyllum oil using zinc doped calcium oxide (Plaster of Paris) nanocatalyst. Bioresour. Technol. 2019, 280, 493-496. [CrossRef]

66. Umdu, E.S.; Tuncer, M.; Seker, E. Transesterification of Nannochloropsis oculata microalga's lipid to biodiesel on Al2O3 supported $\mathrm{CaO}$ and $\mathrm{MgO}$ catalysts. Bioresour. Technol. 2009, 100, 2828-2831. [CrossRef]

67. Wu, H.; Zhang, J.; Wei, Q.; Zheng, J.; Zhang, J. Transesterification of soybean oil to biodiesel using zeolite supported CaO as strong base catalysts. Fuel Process. Technol. 2013, 109, 13-18. [CrossRef] 
68. Chen, G.-Y.; Shan, R.; Shi, J.; Yan, B.-B. Transesterification of palm oil to biodiesel using rice husk ash-based catalysts. Fuel Process. Technol. 2015, 133, 8-13. [CrossRef]

69. Vardast, N.; Haghighi, M.; Dehghani, S. Sono-dispersion of calcium over Al-MCM-41used as a nanocatalyst for biodiesel production from sunflower oil: Influence of ultrasound irradiation and calcium content on catalytic properties and performance. Renew. Energy 2019, 132, 979-988. [CrossRef]

70. Rabie, A.M.; Shaban, M.; Abukhadra, M.R.; Hosny, R.; Ahmed, S.A.; Negm, N. Diatomite supported by CaO/MgO nanocomposite as heterogeneous catalyst for biodiesel production from waste cooking oil. J. Mol. Liq. 2019, 279, 224-231. [CrossRef]

71. Lani, N.S.; Ngadi, N.; Yahya, N.Y.; Rahman, R.A. Synthesis, characterization and performance of silica impregnated calcium oxide as heterogeneous catalyst in biodiesel production. J. Clean. Prod. 2017, 146, 116-124. [CrossRef]

72. Reyero, I.; Moral, A.; Bimbela, F.; Radosevic, J.; Sanz, O.; Montes, M.; Gandía, L.M. Metallic monolithic catalysts based on calcium and cerium for the production of biodiesel. Fuel 2016, 182, 668-676. [CrossRef]

73. Nisar, J.; Razaq, R.; Farooq, M.; Iqbal, M.; Khan, R.A.; Sayed, M.; Shah, A.; Rahman, I.U. Enhanced biodiesel production from Jatropha oil using calcined waste animal bones as catalyst. Renew. Energy 2017, 101, 111-119. [CrossRef]

74. Wilkanowicz, S.I.; Hollingsworth, N.R.; Saud, K.; Kadiyala, U.; Larson, R.G. Immobilization of calcium oxide onto polyacrylonitrile (PAN) fibers as a heterogeneous catalyst for biodiesel production. Fuel Process. Technol. 2020, 197, 106214. [CrossRef]

75. Al-Jammal, N.; Al-Hamamre, Z.; Alnaief, M. Manufacturing of zeolite based catalyst from zeolite tuft for biodiesel production from waste sunflower oil. Renew. Energy 2016, 93, 449-459. [CrossRef]

76. De Vasconcellos, A.; Laurenti, J.B.; Miller, A.H.; da Silva, D.A.; de Moraes, F.R.; Aranda, D.A.; Nery, J.G. Potential new biocatalysts for biofuel production: The fungal lipases of Thermomyces lanuginosus and Rhizomucor miehei immobilized on zeolitic supports ion exchanged with transition metals. Microporous Mesoporous Mater. 2015, 214, 166-180. [CrossRef]

77. Pratap, S.; Shamshuddin, S.; Thimmaraju, N.; Shyamsundar, M.; Reena, S. Kinetics of transesterification of Madhuca Indica oil over modified zeolites: Biodiesel synthesis. Bangladesh J. Sci. Ind. Res. 2015, 50, 271-278. [CrossRef]

78. Sun, C.; Qiu, F.; Yang, D.; Ye, B. Preparation of biodiesel from soybean oil catalyzed by Al-Ca hydrotalcite loaded with K2CO3 as heterogeneous solid base catalyst. Fuel Process. Technol. 2014, 126, 383-391. [CrossRef]

79. Zein, Y.M.; Anal, A.K.; Prasetyoko, D.; Qoniah, I. Biodiesel Production from Waste Palm Oil Catalyzed by Hierarchical ZSM-5 Supported Calcium Oxide. Indones. J. Chem. 2016, 16, 98-104. [CrossRef]

80. Pavlović, S.M.; Marinković, D.M.; Kostić, M.D.; Lončarević, D.R.; Mojović, L.V.; Stanković, M.V.; Veljković, V.B. The chicken eggshell calcium oxide ultrasonically dispersed over lignite coal fly ash-based cancrinite zeolite support as a catalyst for biodiesel production. Fuel 2021, 289, 119912. [CrossRef]

81. Zhang, Y.; Niu, S.; Han, K.; Li, Y.; Lu, C. Synthesis of the SrO-CaO-Al2O3 trimetallic oxide catalyst for transesterification to produce biodiesel. Renew. Energy 2021, 168, 981-990. [CrossRef]

82. Witoon, T.; Bumrungsalee, S.; Vathavanichkul, P.; Palitsakun, S.; Saisriyoot, M.; Faungnawakij, K. Biodiesel production from transesterification of palm oil with methanol over $\mathrm{CaO}$ supported on bimodal meso-macroporous silica catalyst. Bioresour. Technol. 2014, 156, 329-334. [CrossRef]

83. Ho, W.W.S.; Ng, H.K.; Gan, S.; Tan, S.H. Evaluation of palm oil mill fly ash supported calcium oxide as a heterogeneous base catalyst in biodiesel synthesis from crude palm oil. Energy Convers. Manag. 2014, 88, 1167-1178. [CrossRef]

84. Xie, W.; Zhao, L. Production of biodiesel by transesterification of soybean oil using calcium supported tin oxides as heterogeneous catalysts. Energy Convers. Manag. 2013, 76, 55-62. [CrossRef]

85. Wan, Z.; Hameed, B.H.; Nor, N.M.; Bashah, N.A.A. Optimization of Methyl Ester Production from Waste Palm Oil Using Activated Carbon Supported Calcium Oxide Catalyst. Solid State Phenom. 2018, 280, 346-352. [CrossRef]

86. Bet-Moushoul, E.; Farhadi, K.; Mansourpanah, Y.; Nikbakht, A.M.; Molaei, R.; Forough, M. Application of CaO-based/Au nanoparticles as heterogeneous nanocatalysts in biodiesel production. Fuel 2016, 164, 119-127. [CrossRef]

87. Ismail, S.; Ahmed, A.S.; Anr, R.; Hamdan, S. Biodiesel Production from Castor Oil by Using Calcium Oxide Derived from Mud Clam Shell. J. Renew. Energy 2016, 2016, 1-8. [CrossRef]

88. Jindapon, W.; Ashokkumar, V.; Rashid, U.; Rojviriya, C.; Pakawanit, P.; Ngamcharussrivichai, C. Production of biodiesel over waste seashell-derived active and stable extrudate catalysts in a fixed-bed reactor. Environ. Technol. Innov. 2020, $20,101051$. [CrossRef]

89. Viriya-Empikul, N.; Krasae, P.; Puttasawat, B.; Yoosuk, B.; Chollacoop, N.; Faungnawakij, K. Waste shells of mollusk and egg as biodiesel production catalysts. Bioresour. Technol. 2010, 101, 3765-3767. [CrossRef]

90. Borges, L.D.; Moura, N.N.; Costa, A.A.; Braga, P.R.; Dias, J.A.; Dias, S.C.; De Macedo, J.L.; Ghesti, G.F. Investigation of biodiesel production by HUSY and Ce/HUSY zeolites: Influence of structural and acidity parameters. Appl. Catal. A Gen. 2013, 450, 114-119. [CrossRef]

91. Kesić, Ž.; Lukić, I.; Zdujić, M.; Mojović, L.; Skala, D. Calcium oxide based catalysts for biodiesel production: A review. Chem. Ind. Chem. Eng. Q. 2016, 10.

92. Mohiddin, M.N.; Saleh, A.; Reddy, A.N.; Hamdan, S. Turritella terebra Shell Synthesized Calcium Oxide Catalyst for Biodiesel Production from Chicken Fat. Mater. Sci. Forum 2020, 997, 93-101. [CrossRef]

93. Yuliana, M.; Santoso, S.P.; Soetaredjo, F.E.; Ismadji, S.; Angkawijaya, A.E.; Irawaty, W.; Ju, Y.-H.; Tran-Nguyen, P.L.; Hartono, S.B. Utilization of waste capiz shell—Based catalyst for the conversion of leather tanning waste into biodiesel. J. Environ. Chem. Eng. 2020, 8, 104012. [CrossRef] 
94. Lin, Y.-C.; Amesho, K.T.; Chen, C.-E.; Cheng, P.-C.; Chou, F.-C. A cleaner process for green biodiesel synthesis from waste cooking oil using recycled waste oyster shells as a sustainable base heterogeneous catalyst under the microwave heating system. Sustain. Chem. Pharm. 2020, 17, 100310. [CrossRef]

95. Thakur, S.; Singh, S.; Pal, B. Superior adsorption removal of dye and high catalytic activity for transesterification reaction displayed by crystalline $\mathrm{CaO}$ nanocubes extracted from mollusc shells. Fuel Process. Technol. 2021, 213, 106707. [CrossRef]

96. Norwazan, A.; Norzaima, N.; Rosdzimin, A.; Rahim, A.M. Waste cooking oil biodiesel conversion using CaO of mussel shell as a heterogeneous catalyst. Adv. Nat. Appl. Sci. 2020, 14, 280-287.

97. Niju, S.; Rabia, R.; Devi, K.S.; Kumar, M.N.; Balajii, M. Modified Malleus malleus Shells for Biodiesel Production from Waste Cooking Oil: An Optimization Study Using Box-Behnken Design. Waste Biomass Valorization 2020, 11, 793-806. [CrossRef]

98. Niju, S.; Vishnupriya, G.; Balajii, M. Process optimization of Calophyllum inophyllum-waste cooking oil mixture for biodiesel production using Donax deltoides shells as heterogeneous catalyst. Sustain. Environ. Res. 2019, 29, 18. [CrossRef]

99. Pandit, P.R.; Fulekar, M. Biodiesel production from microalgal biomass using CaO catalyst synthesized from natural waste material. Renew. Energy 2019, 136, 837-845. [CrossRef]

100. Yin, X.; Duan, X.; You, Q.; Dai, C.; Tan, Z.; Zhu, X. Biodiesel production from soybean oil deodorizer distillate usingcalcined duck eggshell as catalyst. Energy Convers. Manag. 2016, 112, 199-207. [CrossRef]

101. Roschat, W.; Siritanon, T.; Kaewpuang, T.; Yoosuk, B.; Promarak, V. Economical and green biodiesel production process using river snail shells-derived heterogeneous catalyst and co-solvent method. Bioresour. Technol. 2016, 209, 343-350. [CrossRef]

102. Jindapon, W.; Jaiyen, S.; Ngamcharussrivichai, C. Seashell-derived mixed compounds of Ca, $\mathrm{Zn}$ and $\mathrm{Al}$ as active and stable catalysts for the transesterification of palm oil with methanol to biodiesel. Energy Convers. Manag. 2016, 122, 535-543. [CrossRef]

103. Indarti, E. Hydrated calcined Cyrtopleura costata seashells as an effective solid catalyst for microwave-assisted preparation of palm oil biodiesel. Energy Convers. Manag. 2016, 117, 319-325. [CrossRef]

104. Anr, R.; Saleh, A.A.; Islam, S.; Hamdan, S.; Maleque, A. Biodiesel Production from Crude Jatropha Oil using a Highly Active Heterogeneous Nanocatalyst by Optimizing Transesterification Reaction Parameters. Energy Fuels 2015, 30, 334-343. [CrossRef]

105. Lee, S.L.; Wong, Y.C.; Tan, Y.P.; Yew, S.Y. Transesterification of palm oil to biodiesel by using waste obtuse horn shell-derived CaO catalyst. Energy Convers. Manag. 2015, 93, 282-288. [CrossRef]

106. Sirisomboonchai, S.; Abuduwayiti, M.; Guan, G.; Samart, C.; Abliz, S.; Hao, X.; Kusakabe, K.; Abudula, A. Biodiesel production from waste cooking oil using calcined scallop shell as catalyst. Energy Convers. Manag. 2015, 95, 242-247. [CrossRef]

107. Suwanthai, W.; Punsuvon, V.; Vaithanomsat, P. Optimization of biodiesel production from a calcium methoxide catalyst using a statistical model. Korean J. Chem. Eng. 2016, 33, 90-98. [CrossRef]

108. Syazwani, O.N.; Rashid, U.; Yap, Y.H.T. Low-cost solid catalyst derived from waste Cyrtopleura costata (Angel Wing Shell) for biodiesel production using microalgae oil. Energy Convers. Manag. 2015, 101, 749-756. [CrossRef]

109. Zamberi, M.; Ani, F. Biodiesel production from high FFA rubber seed oil using waste cockles. ARPN J. Eng. Appl. Sci. 2016, 11, 7782-7787.

110. Nair, P.; Singh, B.; Upadhyay, S.; Sharma, Y. Synthesis of biodiesel from low FFA waste frying oil using calcium oxide derived from Mereterix mereterix as a heterogeneous catalyst. J. Clean. Prod. 2012, 29, 82-90. [CrossRef]

111. Sharma, Y.C.; Singh, B.; Korstad, J. Application of an Efficient Nonconventional Heterogeneous Catalyst for Biodiesel Synthesis from Pongamia pinnata Oil. Energy Fuels 2010, 24, 3223-3231. [CrossRef]

112. Cho, Y.B.; Seo, G. High activity of acid-treated quail eggshell catalysts in the transesterification of palm oil with methanol. Bioresour. Technol. 2010, 101, 8515-8519. [CrossRef]

113. Suryaputra, W.; Winata, I.; Indraswati, N.; Ismadji, S. Waste capiz (Amusium cristatum) shell as a new heterogeneous catalyst for biodiesel production. Renew. Energy 2013, 50, 795-799. [CrossRef]

114. Jaiyen, S.; Naree, T.; Ngamcharussrivichai, C. Comparative study of natural dolomitic rock and waste mixed seashells as heterogeneous catalysts for the methanolysis of palm oil to biodiesel. Renew. Energy 2015, 74, 433-440. [CrossRef]

115. Boro, J.; Konwar, L.J.; Thakur, A.J.; Deka, D. Ba doped CaO derived from waste shells of Tstriatula (TS-CaO) as heterogeneous catalyst for biodiesel production. Fuel 2014, 129, 182-187. [CrossRef]

116. Mohan, S. Studies on optimization of biodiesel production-snail shell as eco-friendly catalyst by transesterification of neem oil. Int. J. Innov. Res. Technol. Sci. Eng. 2015, 1, 5-10.

117. Yan, S.; Lu, H.; Liang, B. Supported CaO Catalysts Used in the Transesterification of Rapeseed Oil for the Purpose of Biodiesel Production. Energy Fuels 2007, 22, 646-651. [CrossRef]

118. Piker, A.; Tabah, B.; Perkas, N.; Gedanken, A. A green and low-cost room temperature biodiesel production method from waste oil using egg shells as catalyst. Fuel 2016, 182, 34-41. [CrossRef]

119. Romero, R.; Natividad, R.; Martínez, S.L. Biodiesel Production by Using Heterogeneous Catalysts; INTECH Open Access Publisher: London, UK, 2011.

120. Perea, A.; Kelly, T.; Hangun-Balkir, Y. Utilization of waste seashells and Camelina sativa oil for biodiesel synthesis. Green Chem. Lett. Rev. 2016, 9, 27-32. [CrossRef]

121. Dehkordi, A.M.; Ghasemi, M. Transesterification of waste cooking oil to biodiesel using Ca and Zr mixed oxides as heterogeneous base catalysts. Fuel Process. Technol. 2012, 97, 45-51. [CrossRef]

122. De Lima, A.L.; Ronconi, C.M.; Mota, C.J.A. Heterogeneous basic catalysts for biodiesel production. Catal. Sci. Technol. 2016, 6, 2877-2891. [CrossRef] 
123. Hsiao, M.-C.; Lin, C.-C.; Chang, Y.-H. Microwave irradiation-assisted transesterification of soybean oil to biodiesel catalyzed by nanopowder calcium oxide. Fuel 2011, 90, 1963-1967. [CrossRef]

124. Yoosuk, B.; Udomsap, P.; Puttasawat, B.; Krasae, P. Improving transesterification acitvity of CaO with hydration technique. Bioresour. Technol. 2010, 101, 3784-3786. [CrossRef] [PubMed]

125. Zhang, J.; Chen, S.; Yang, R.; Yan, Y. Biodiesel production from vegetable oil using heterogenous acid and alkali catalyst. Fuel 2010, 89, 2939-2944. [CrossRef]

126. Zamberi, M.M.; Ani, F.N.; Abdollah, M.F. Heterogeneous transesterification of rubber seed oil biodiesel production. J. Teknol. 2016, 78. [CrossRef]

127. Kouzu, M.; Kajita, A.; Fujimori, A. Catalytic activity of calcined scallop shell for rapeseed oil transesterification to produce biodiesel. Fuel 2016, 182, 220-226. [CrossRef]

128. Mohadesi, M.; Hojabri, Z.; Moradi, G. Biodiesel production using alkali earth metal oxides catalysts synthesized by sol-gel method. Biofuel Res. J. 2014, 1, 30-33. [CrossRef]

129. Umdu, E.S.; Seker, E. Transesterification of sunflower oil on single step sol-gel made Al2O3 supported CaO catalysts: Effect of basic strength and basicity on turnover frequency. Bioresour. Technol. 2012, 106, 178-181. [CrossRef] [PubMed]

130. Su, M.; Yang, R.; Li, M. Biodiesel production from hempseed oil using alkaline earth metal oxides supporting copper oxide as bi-functional catalysts for transesterification and selective hydrogenation. Fuel 2013, 103, 398-407. [CrossRef]

131. Meng, Y.-L.; Wang, B.-Y.; Li, S.-F.; Tian, S.-J.; Zhang, M.-H. Effect of calcination temperature on the activity of solid Ca/Al composite oxide-based alkaline catalyst for biodiesel production. Bioresour. Technol. 2013, 128, 305-309. [CrossRef] [PubMed]

132. Al-Zaini, E.O.; Olsen, J.; Nguyen, T.H.; Adesina, A. Transesterification of Waste Cooking Oil in Presence of Crushed Seashell as a Support for Solid Heterogeneous Catalyst. SAE Int. J. Fuels Lubr. 2011, 4, 139-157. [CrossRef]

133. Son, S.M.; Kusakabe, K. Transesterification of sunflower oil in a countercurrent trickle-bed reactor packed with a CaO catalyst. Chem. Eng. Process. Process. Intensif. 2011, 50, 650-654. [CrossRef]

134. Baroutian, S.; Aroua, M.K.; Raman, A.A.A.; Sulaiman, N.M. A packed bed membrane reactor for production of biodiesel using activated carbon supported catalyst. Bioresour. Technol. 2011, 102, 1095-1102. [CrossRef] [PubMed]

135. Buasri, A.; Chaiyut, N.; Loryuenyong, V.; Rodklum, C.; Chaikwan, T.; Kumphan, N. Continuous Process for Biodiesel Production in Packed Bed Reactor from Waste Frying Oil Using Potassium Hydroxide Supported on Jatropha curcas Fruit Shell as Solid Catalyst. Appl. Sci. 2012, 2, 641-653. [CrossRef]

136. Mootabadi, H.; Salamatinia, B.; Bhatia, S.; Abdullah, A.Z. Ultrasonic-assisted biodiesel production process from palm oil using alkaline earth metal oxides as the heterogeneous catalysts. Fuel 2010, 89, 1818-1825. [CrossRef]

137. Chen, G.-Y.; Shan, R.; Yan, B.-B.; Shi, J.; Li, S.-Y.; Liu, C.-Y. Remarkably enhancing the biodiesel yield from palm oil upon abalone shell-derived $\mathrm{CaO}$ catalysts treated by ethanol. Fuel Process. Technol. 2016, 143, 110-117. [CrossRef]

138. Shan, R.; Zhao, C.; Lv, P.; Yuan, H.; Yao, J. Catalytic applications of calcium rich waste materials for biodiesel: Current state and perspectives. Energy Convers. Manag. 2016, 127, 273-283. [CrossRef]

139. Silitonga, A.; Shamsuddin, A.; Mahlia, T.M.I.; Milano, J.; Kusumo, F.; Siswantoro, J.; Dharma, S.; Sebayang, A.; Masjuki, H.; Ong, H.C. Biodiesel synthesis from Ceiba pentandra oil by microwave irradiation-assisted transesterification: ELM modeling and optimization. Renew. Energy 2020, 146, 1278-1291. [CrossRef]

140. Tan, S.X.; Lim, S.; Ong, H.C.; Pang, Y.L. State of the art review on development of ultrasound-assisted catalytic transesterification process for biodiesel production. Fuel 2019, 235, 886-907. [CrossRef] 